by Christian Meister ${ }^{1}$, Martin Aberhan ${ }^{2}$, Joachim Blau ${ }^{3}$, Jean-Louis Dommergues ${ }^{4}$, Susanne Feist-Burkhardt ${ }^{5}$, Ernie A. Hailwood ${ }^{6}$, Malcom Hart $^{7}$, Stephen P. Hesselbo ${ }^{8}$, Mark W. Hounslow ${ }^{9}$, Mark Hylton ${ }^{7}$, Nicol Morton ${ }^{10}$, Kevin Page ${ }^{7}$, and Greg D. Price ${ }^{7}$

\title{
The Global Boundary Stratotype Section and Point (GSSP) for the base of the Pliensbachian Stage (Lower Jurassic), Wine Haven, Yorkshire, UK
}

1 Département de Géologie et de Paléontologie, 1, route de Malagnou, c.p. 6434, CH-1211 Genève 6, Switzerland.

E-mail: christian.meister@mhn.ville-ge.ch

2 Museum der Naturkunde, Zentralinstitut der Humboldt-Universität zu Berlin, Institut für Paläontolgie, Invalidenstr. 43, D-10115 Berlin, Germany.E-mail: martin.aberhan@rz.hu-berlin.de

3 Institut für Geowissenschaften, Diezstrasse 15, D-35390 Giessen, Germany. E-mail: joachim.blau@geolo.uni-giessen.de

4 Centre des Sciences de la Terre de l'Université de Bourgogne, UMR CNRS 5561: Paléontologie analytique et Géologie sédimentaire, 6

Boulevard Gabriel, F-21100 Dijon.France.E-mail: jean-louis.dommergues@u-bourgogne.fr

5 Department of Palaeontology, The Natural History Museum, Cromwell Road, London, SW7 5BD, UK.E-mail:S.Feist-Burkhardt@nhm.ac.uk

6 Core Magnetics, The Green, Sedbergh, Cumbria, LA10 5JS, UK.E-mail: hailwood@coremagnetics.com

7 Department of Geological Sciences, University of Plymouth, Drake Circus, Plymouth, Devon PL4 8AA, UK.

E-mail:M.Hart@plymouth.ac.uk;KevinP@bello-page.fsnet.co.uk

8 Department of Earth Sciences, University of Oxford, Parks Road, Oxford OX1 3PR, UK. E-mail: stephen.hesselbo@earth.ox.ac.uk

9 CEMP, Geography Dept. Lancaster Environment Centre, Lancaster University, Bailrigg, Lancaster, UK. LA1 4YB.

E-mail:m.Hounslow@lancaster.ac.uk

10 Le Chardon, Quartier Brugière, F-07200 Vogüé, France.E-mail: nicol.morton@wanadoo.fr

Following votes by the Pliensbachian Working Group, the Jurassic Subcommission and the International Commission on Stratigraphy, IUGS ratified the proposed Global Boundary Stratotype Section and Point (GSSP) for the base of the Pliensbachian Stage (Lower Jurassic) at the base of bed 73b in the Wine Haven section, Robin Hood's Bay, Yorkshire Coast, UK. This level contains the characteristic ammonite association Bifericeras donovani Dommergues and Meister and Apoderoceras sp. Complementary data include: a) Strontium-isotope stratigraphy, based on analysis of belemnites which yield a calcite ${ }^{87} \mathrm{Sr} /{ }^{86} \mathrm{Sr}$ ratio for the boundary level of 0.707425 and data supporting interpretation of continuous sedimentation; b) Belemnite oxygen-isotope data indicate a significant temperature drop $\left(\sim 5^{\circ} \mathrm{C}\right)$ across the boundary at this locality; c) A Transgressive Systems Tract (TST) initiated in the Aplanatum Subzone (uppermost Sinemurian) continues into the Lowermost Pliensbachian (Taylori Subzone); it forms part of a transgressive facies cycle sensu Graciansky et al. (1998); d) The Upper Sinemurian to lowermost Pliensbachian at Wine Haven section has a predominantly normal magnetic polarity, but two discrete reversed polarity magnetozones are present. The first spans much of the latest Sinemurian Aplanatum Subzone. It terminates $<0.5 m$ below the Sinemurian-Pliensbachian boundary and may prove a valuable chronostratigraphic marker. The second extends from the latest Oxynotum Subzone probably through to the lower part of the Raricostatum Subzone.

\section{Foreword}

The Pliensbachian is the third Stage of the Jurassic System, and the fourth Jurassic Stage to be defined by a GSSP. Jurassic Stages were first named by A. d'Orbigny in the 1840's and seven of the eleven Global Standard Stages currently recognised were named by him. This is despite numerous additions and revisions by subsequent authors and is due to the influence of W.J. Arkell in the 1950s and the Jurassic Subcommission from the 1960s in limiting the number of Stages recognised officially as the Global Standard. As it happens, the name Pliensbachian was introduced by A. Oppel in 1858 to replace d'Orbigny's name 'Liasien' and was adopted internationally.

From d'Orbigny until the 1960s, Jurassic Stages have been traditionally defined by the Standard (ammonite) Zones they contain. For example, the Pliensbachian was defined, following Oppel, as having the 'Zone des Amm. Jamesoni' at the base and the 'Zone des Amm. Spinatus' at the top. The Jurassic Subcommission accepted the internationally agreed requirement for more precise definitions of the bases of Stages at a point in a stratotype section. Working Groups were established for each Stage, to recommend basal boundary stratotypes. The task of the Pliensbachian WG, as with several others, was made more difficult by the presence of a widespread hiatus, limiting the number of sections available with a continuous record of sedimentation across the basal (Sinemurian-Pliensbachian) boundary interval. The availability in this interval, as in many parts of the Jurassic, of extremely precise relative dating and correlation based on ammonite biochronology, has been crucial to the successful overcoming of this problem by the Pliensbachian Working Group.

The original proposal by the Group was accepted by the Jurassic Subcommission and published (in Eclogae Geologicae Helvetiae) in 2003. Before submission to the International Commission on Stratigraphy in 2004 it became possible to incorporate the results from a preliminary palaeomagnetic survey (partly sponsored by the Jurassic Subcommission) and various other suggested modifications. The proposal was accepted unanimously by ICS in 2004 and ratified 
by IUGS in March 2005. For this Episodes paper some additional data on international correlations have been included.

\section{Introduction}

The present paper, defining the Global Boundary Stratotype Section and Point (GSSP) for the base of the Pliensbachian Stage, is the result of intensive work by the Pliensbachian Working Group (C. Meister, convenor). The proposal document submitted for voting to all members of the Pliensbachian Working Group and Voting Members of the Jurassic Subcommission was published in 2003 (Meister et al.). The results of the votes were: Pliensbachian Working Group - 28 YES, 3 ABSTAIN, 0 NO; Jurassic Subcommission - 18 YES, 0 ABSTAIN, 0 NO. The present paper that summarizes previous works and reports from members of the Pliensbachian Working Group (Dommergues and Meister, 1992; Hesselbo et al., 2000; Meister, ISJS Newsletter 1997, 1999a, 1999b, 2001, 2002, 2003, 2004, 2005; Howarth, 2002; Meister et al., 2003) is completed by integrated zonation and correlation tables for ammonites, belemnites, brachiopods, ostracods, foraminifera, dinoflagellate cysts, calcareous nannofossils, bivalves and by the results of the paleomagnetostratigraphy. It is the official presentation of the GSSP for the base of the Pliensbachian Stage.

\section{Historical Background}

The classic foreshore and cliff exposures of the Lower Lias in Robin Hood's Bay are undoubtedly one of the most important and complete mid-Sinemurian to Pliensbachian sequences in Europe (Figure 1). The earliest scientific references to the site are probably those within Young and Bird's famous 1822 volume describing the Yorkshire coast as a whole, followed by Williamson in 1840 . Surprisingly the only detailed published description of the lower part of the section (Sinemurian to Lower Pliensbachian) is within Tate and Blake's classic work "The Yorkshire Lias" (1876), more than 125 years old (and reproduced many times by later authors such as Fox-Strangeways and Barrow (1882) and Buckman (1915). This is not because the sequence has received no subsequent attention, indeed Bairstow spent many years, from at least the 1930s, carefully mapping and measuring the shore, but never published anything more than a brief summary (e.g. in SylvesterBradley, 1953 and in Hemingway et al., 1968, 1969). The copious notes and specimens he left are now in the Natural History Museum in London, and have been revised and published (Howarth, 2002).

Partial sections, supported by bed-by-bed description, are available in Howarth (1955), Getty (1972, 1973), Gad (1966), Phelps (1985) and Dommergues and Meister (1992). Hesselbo and Jenkyns (1995) provide a complete graphic log from the Sine- murian to the Toarcian. Further notes and observations are incorporated into field excursion guides to the area, such as Wright in Rawson and Wright (1992) and Senior (1996). A number of the formal lithostratigraphic units of the Cleveland basin Lower Jurassic sequence have type localities and reference sections in Robin Hood's Bay, including the Siliceous Shales, Pyritous Shales and Ironstone Shales "members" of the Redcar Mudstone Formation (Powell, 1984; Cox, 1990).

Sedimentological aspects of the sections have also been studied, especially within the Pliensbachian, and these include Hallam (1967), Sellwood (1971), Greensmith et al. (1980) and Howard (1985), but the most frequent references to Robin Hood's Bay are in the taxonomic and stratigraphic descriptions of ammonite faunas (Young and Bird, 1828; Simpson, 1843, 1855, 1865-68; Buckman, 1909-1930; Tate and Blake, 1876; Spath, 1925; Howarth, 1955, 1958, 1992; Getty, 1972, 1973; Dommergues and Meister, 1992). Significantly, the sections in Robin Hood's Bay figure prominently in a number of stratigraphic reviews, most importantly as stratotypes, both historical and actual, for zonal units at the level of chronozone, subchronozone and horizon (e.g., Buckman, 1915; Dean et al., 1961; Phelps, 1985; Page, 1992; Howarth, 1992; Dommergues et al., 1994; Blau and Meister, 2000) and figure prominantly in reviews of the stratigraphy and correlations of the Cleveland Basin (e.g. Cope et al., 1980; Howard, 1985; Hesselbo and Jenkyns, 1995; Rawson and Wright, 1995). A key development in

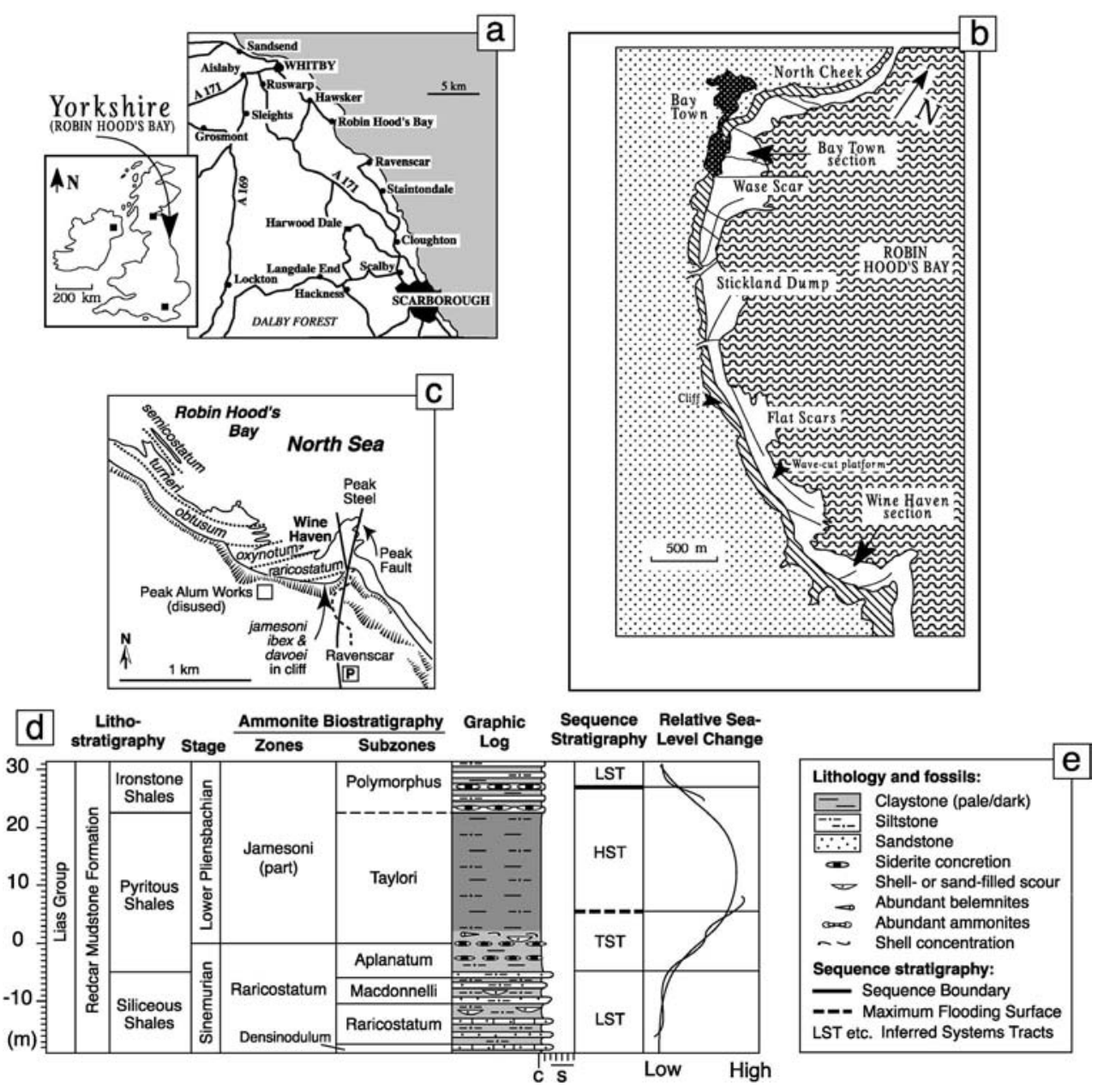

Figure 1 Wine Haven section. (a, b) Location of Robin Hood's Bay, Yorkshire, UK (from Dommergues and Meister 1992). (c) Detailed sketch geological map of the Wine Haven area (adapted from Rawson and Wright, 1992). (d) Summary stratigraphic log for the Late Sinemurian to Early Pliensbachian succession of Robin Hood's Bay, Yorkshire, based on data in Hesselbo and Jenkyns $(1995,1998)$ and Cope et al. (1980). The sea-level curves are of 3rd and 4th order sensu Graciansky et al. (1998). (e) Key to panel (d) and Figure 4 (from Hesselbo et al., 2000 partim and Meister et al., 2003). 
this field is the identification of the exposures in the southern part of the bay. The boundary between Sinemurian and Pliensbachian strata occurs within the Redcar Mudstone Formation (Powell, 1984) and is particularly well exposed on wave-washed rock platforms and at the foot of the cliff on the south side of the bay, at Wine Haven, a former harbour that served the adjacent Peak Alum Works. Following the description of the stratigraphy and sedimentology by Hesselbo and Jenkyns (1995) for the Robin Hood's Bay area of Yorkshire 'The Hettangian to mid-Pliensbachian strata are predominantly mudstone with subordinate sandy and Fe-rich intervals'. The Redcar Mudstone (Powell, 1984), is subdivided into a number of informal units correlatable within the basin. Sandstone beds are developed in the Upper Sinemurian Siliceous Shales, whereas mudstone dominates both below, in the Lower Sinemurian Calcareous Shales, and above, in the lower Pliensbachian Pyritous and Ironstone Shales. Organic-rich shales are developed in the lowermost Pliensbachian (Jamesoni Zone) 'Pyritous Shales'.

A review of the Wine Haven section at the Sinemurian-Pliensbachian boundary together with comparisons with European ammonite faunas (Dommergues and Meister, 1992) has indicated that this section exhibits the most complete ammonite faunal succession known from the European region, thus spotlighting its potential as a Global Stratotype Section and Point (GSSP) for the base of the Pliensbachian Stage.

\section{The Global Boundary Stratotype Section and Point (GSSP) for the base of the Pliensbachian Stage}

\section{Location}

The GSSP (Wine Haven) is located about $3 \mathrm{~km} \mathrm{S-SE}$ of the small town of Robin Hood's Bay, Yorkshire, UK (Figures 1a-c, 2A, B).

\section{Coordonates}

UK grid reference NZ 97620230

Longitude $0^{\circ} 29^{\prime} 51 " \mathrm{~W}$ (nearly on the Greenwich meridian) Latitude $54^{\circ} 24^{\prime} 25^{\prime \prime} \mathrm{N}$

Very easily accessible from Whitby or Scarborough, the GSSP can be reached by foot from Bay Town along the coast or more directly from the Ravenscar parking.

\section{Protection of the site}

The Wine Haven section (Robin Hood's Bay) already forms part of a Site of Special Scientific Interest, protected by law through the Countryside and Rights of Way Act 2001 (and previously through the Wildlife and Countryside Act 1981). This statutory protection will not change, but it is a good system of national conservation law. This protection does not stop responsible collection of material for geological research but this $<$ freedom $>$ is, of course open to abuse by fossil collectors.

\section{Description of the GSSP}

The Sinemurian-Pliensbachian sequence is well developed in Robin Hood's Bay and contains a complete succession of quite wellpreserved ammonite assemblages. The Sinemurian-Pliensbachian boundary succession lies within the Pyritous Shales Member and comprises pale grey and buff-coloured sandy mudstones which pass upwards into silty dark grey shales (Sellwood, 1970; Hesselbo and Jenkyns, 1995)

The lithologies of the Raricostatum and Jamesoni Zones are fairly uniform, with ammonites in almost every bed and the upward transition from pale grey to dark grey shale is gradational. In the field, two of the most noticeable features of this interval are the 10$\mathrm{cm}$-thick beds of concretionary siderite (Figures 2A, B and 3: bed
72). Above the upper concretionary level, macrofossils are abundant, and are concentrated into several discrete shell-beds. The whole succession was deposited in a shallow-marine environment, but the facies sequence from the upper part of the Sinemurian (Aplanatum Subzone) to the lower part of the Pliensbachian (Taylori Subzone) represents a long-term relative sea-level rise of at least regional extent, possibly global (Hallam, 1961, 1981; Sellwood, 1971; Hesselbo and Jenkyns, 1995, 1998; Van Buchem and Knox, 1998; Hesselbo et al., 2000) (Figure 1d).

The Yorkshire coast successions of the Cleveland Basin have been remeasured and interpreted in the context of sequence stratigraphy by Hesselbo and Jenkyns (1998). The Sinemurian-Pliensbachian boundary at Wine Haven lies within a sequence that generally progresses upwards from relatively pale and thoroughly bioturbated sandy mudstone into dark shales, a change that takes place over some $20 \mathrm{~m}$, but is particularly well marked at the boundary itself. Superimposed on this overall facies change are smaller-scale $(0.5-5 \mathrm{~m})$ alternations of coarser and finer sediment. In terms of sequence stratigraphy, the succession can be interpreted with some confidence as a transgressive systems tract and the sediments record an overall deepening of at least regional extent (Sellwood, 1971; Hesselbo and Jenkyns, 1995, 1998).
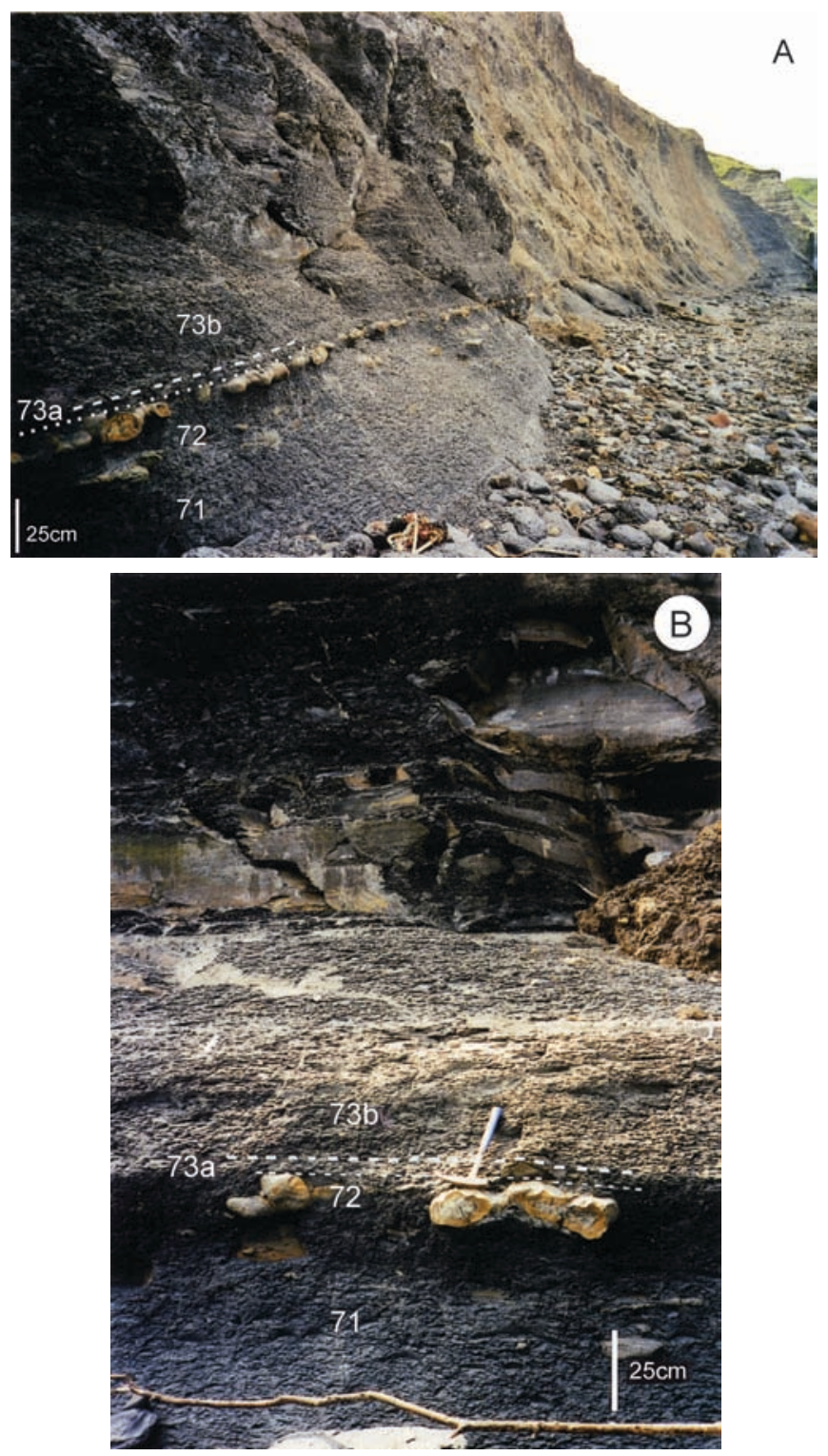

Figure 2 Wine Haven outcrop, (A-B) Lithological sequence at the Sinemurian-Pliensbachian boundary, bed $73 b$ indicates (broken line) the base of the Pliensbachian (from Meister et al., 2003). 


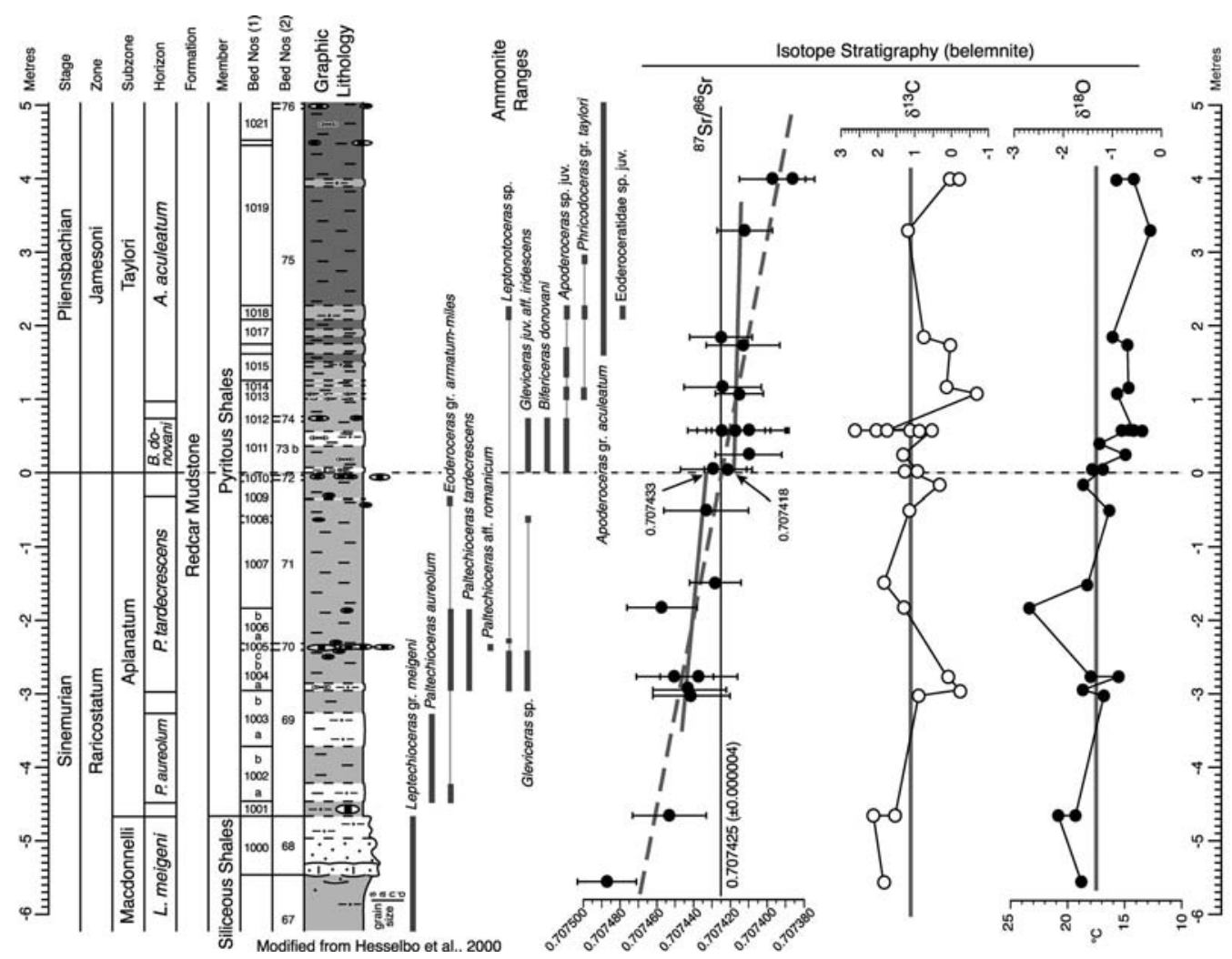

Figure 3 Detailed log of the Sinemurian-Pliensbachian boundary section at Wine Haven, Robin Hood's Bay. Bed numbers are from Dommergues and Meister (1992) ${ }^{1}$ (beds 1000-1021) and Hesselbo and Jenkyns (1995) ${ }^{2}$ (beds 67-76). Key as for Figure 1. Isotopic values are from diagenetically unaltered samples only. No ammonites have been recorded from between - 0.36 to $0 \mathrm{~m}$ in the section (from Hesselbo et al., 2000, partim from Howarth, 2002 figure 23, p. 147 and Meister et al., 2003).

Higher in the succession - in the Ironstone Shales, above the Taylori Subzone - the succession is again charaterized by lithological cyclicity which has been interpreted as a response to Milankovitch climate forcing (Van Buchem et al., 1992, 1994; Weedon and Jenkyns, 1999). It is possible that the Pyritous Shales (Taylori Subzone) contains a cryptic lithological cyclicity that would allow a Milankovitch-based cyclostratigraphy to be extended across the stage boundary at Wine Haven.

\section{The boundary level and the fossil record}

The diversity of the fossil assemblages is low with a prevalence of the ammonites. If present at this boundary, bivalves, belemnites and brachiopods are very rare and have not been studied. In this section the Foraminifera, Ostracoda and the palynology provide essentially no information for the definition of the boundary by microfossils. At the present time, we have no information about the calcareous nannofossils of this period.

\section{Ammonites: the primary and unique marker}

When d'Orbigny and Oppel described the Sinemurian and Pliensbachian in the middle of the nineteenth century, they located the boundary between these two stages at a level of important faunal changes corresponding roughly to the disappearance of the Echioceratidae (Psiloceratoidea) and the subsequent full development of the Eoderoceratoidea which split up with a significant increase of disparity (morphology) (Dommergues et al., 1996) and diversity (taxonomy) (Meister and Stampfli, 2000). The Psiloceratoidea dominated the first two Jurassic stages, Hettangian and Sinemurian during about 12 my. The second superfamily (Eoderoceratoidea) which dominated the NW European ammonite fauna of the Pliensbachian (about $7 \mathrm{my}$ ) and, with the Dactylioceratidae, persisted through to the middle Toarcian. The Sinemurian-Pliensbachian ammonoid event is a good example of faunal renewal at a global scale. Nevertheless, this period of transition is usually poorly documented where the late Sinemurian and early Pliensbachian strata are exposed.

The base of the Jamesoni Zone (respectively the base of the Taylori Subzone) is traditionally used to determine the base of the Pliensbachian.

In the present case, the base of the first Pliensbachian subzone (Taylori subzone) was defined by Spath (1923) in the Dorset coast section and later discussed by Dean et al. (1961) and other authors. In the Dorset coast section, Spath (1923) and then Lang (1928) indicated the association of Phricodoceras taylori (Sowerby) with Apoderoceras in bed 105 which is considered to be the first bed of the Taylori subzone (see also discussion in Hesselbo and Jenkyns, 1995, p. 115 and 119). This definition allowed authors to recognize the Taylori subzone in the major part of the NW European areas even if the base, often depending on the presence of Phricodoceras gr. taylori (Sowerby) only, could not be determined with sufficient precision. Since Phricodoceras gr. taylori (Sowerby) was already known by rare specimens from the Upper Sinemurian (Dommergues and Meister, 1990; Schlatter, 1990), it became apparent that its record was inadequate to define the base of the Taylori subzone (see Dommergues and Meister, 1992) and the definition of the boundary had to be reconsidered and improved. Consequently, the position of the boundary is now based in NW Europe on particular taxa of the Eoderoceratoidea or on their associations. It is now the presence of species of the genus Apoderoceras [Apoderoceras nodogigas (Quenstedt)-leckenbyi (Wright), Apoderoceras ssp.] or Tetraspidoceras quadrarmatum (Dumortier) which indicate the base of the Pliensbachian. At the present time, only this pattern can be accepted as being the biochronological event which enables recognition of the base of Pliensbachian Stage. The Taylori Subzone can be recognized widely across northwestern Europe (Dommergues and Meister, 1992), although beyond Robin Hood's Bay its base can be identified only tentatively with Eoderoceratid taxa that require further study.

The ammonite assemblages in the Wine Haven section are characterized by material that is quite abundant, easy to sample, and contemporaneous with the sediment deposition. Ammonites are preserved as internal moulds in limestone beds, pyritic phragmocones and crushed body chambers in marly levels.

The succession of these assemblages allows the recognition and characterisation of the subzones and horizons within the Raricostatum Zone in the Upper Sinemurian and the Jamesoni Zone in the lower Pliensbachian. The different associations, grouped into horizons (cf. Callomon, 1995; Blau and Meister, 2000) are compatible with the standard biozonation of Dean et al. (1961) and the succession of horizons proposed by Dommergues et al. $(1994,1997)$ and Meister (1995) (Figures 3 and 4). 


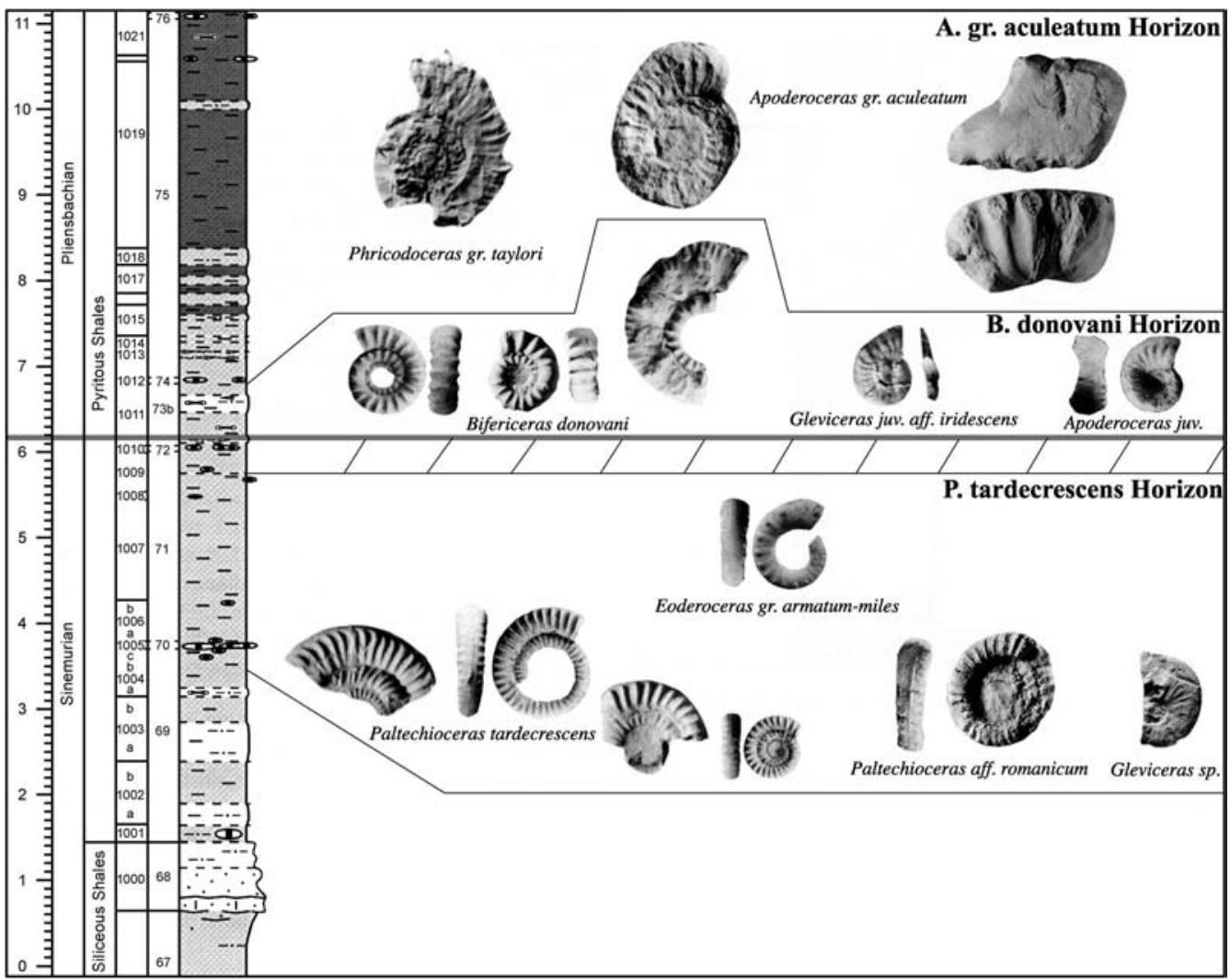

Figure 4 Ammonite faunas and horizons at the Sinemurian-Pliensbachian boundary (from Meister et al., 2003).

\section{UPPER SINEMURIAN}

Upper Raricostatum Zone

Aplanatum Subzone $(4,60 \mathrm{~m}$, levels $69-73 \mathrm{a})$ is characterized by the Paltechioceras gr. aplanatum (Hyatt)-tardecrescens (Hauer) and allied species. Two horizons are recognized in the subzone.

P. aureolum horizon (level 69 partim): Paltechioceras aureolum (Simpson), Eoderoceras gr. armatum (Sowerby)-miles (Simpson)

P. tardecrescens horizon (level 69 partim - 71 partim): Paltechioceras tardecrescens (Hauer), Paltechioceras aff. romanicum (Uhlig), Eoderoceras gr. armatum (Sowerby)-miles (Simpson), Leptonotoceras sp. sensu Blau et al., Gleviceras sp.

The last Gleviceras sp. and Eoderoceras gr. armatum (Sowerby)-miles (Simpson) are recorded from the upper part of bed 71 (Howarth 2002).

\section{LOWER PLIENSBACHIAN}

Lower Jamesoni Zone

Taylori Subzone: (partim, more than $5 \mathrm{~m}$, levels 73b-76)

Two horizons are recognized:

B. donovani horizon (level 73b): Bifericeras donovani Dommergues and Meister (Figure 5), Apoderoceras sp. juv., Gleviceras juv. aff. iridescens (Tutcher and Trueman).

A. gr. aculeatum horizon (level 74-76): Apoderoceras gr. aculeatum (Simpson), Apoderoceras sp. juv., Phricodoceras gr. taylori (Sowerby) Leptonotoceras sp. sensu Blau et al., Eoderoceratidae sp. juv.

Amongst this fossil assemblage, the presence of the genus Apoderoceras provides a useful indication for the first level of the Lower Pliensbachian (see discussion). Consequently, the boundary between the Pliensbachian and Sinemurian stages is placed very close to the base of bed 73, exactly at the base of bed 73b in the Wine Haven section (this means $6 \mathrm{~cm}$ above the mid-line of nodules forming bed 72) (Figure 6) and is charaterized by the association of Apoderoceras sp. and Bifericeras donovani Dommergues and Meister. The ammonite Gleviceras juv. aff. iridescens (Tutcher and Trueman) belongs to this association, too. This fossil assemblage overlies the last Upper Sinemurian Echioceratidae and precedes the first classic Lower Pliensbachian Apoderoceras and Phricodoceras taylori
(Sowerby). We note, however, that ammonites have not been recorded from the $36 \mathrm{~cm}$ of strata below the proposed boundary level (Figure $6)$.

\section{Bivalvia}

In general, Jurassic bivalves are long-ranging, with a mean species longevity of European representatives of 15 Million years (Hallam, 1976). For this reason bivalves rarely contribute significantly to Early Jurassic correlation and zonation. Tentatively, a zonation of Early Jurassic strata in western Europe may be based on the Gryphaea lineage. Early Jurassic members of Gryphaea are abundant and have been studied intensively (e.g. Hallam, 1968, 1982; Johnson, 1993, 1994). Within western Europe, three species have been recognized: Gryphaea arcuata Lamarck from the Angulata Zone to the lower Semicostatum Zone, Gryphaea mccullochi J. de C. Sowerby from the upper Semicostatum Zone to the Jamesoni Zone, and Gryphaea gigantea J. de C. Sowerby from the Ibex Zone to the basal Bajocian. This informal zonation does not permit the identification of the Sinemurian-Pliensbachian stage boundary. A few bivalves are reported, however, whose stratigraphic ranges appar-
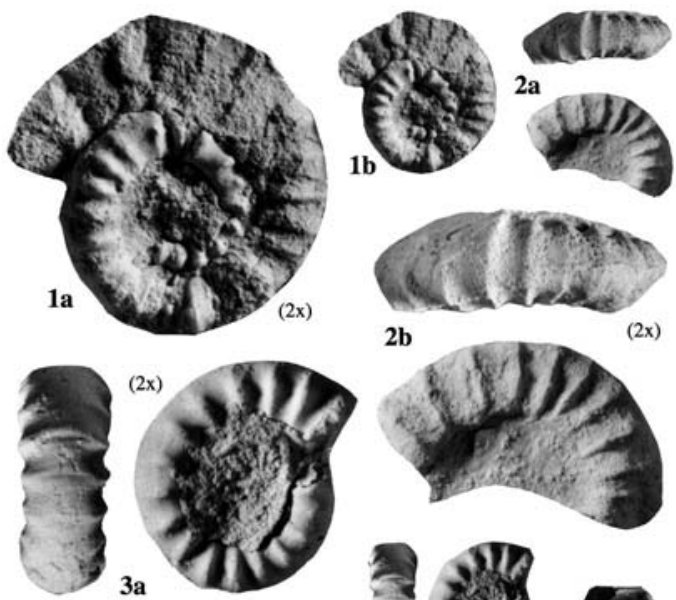

2b $(2 \mathrm{x})$
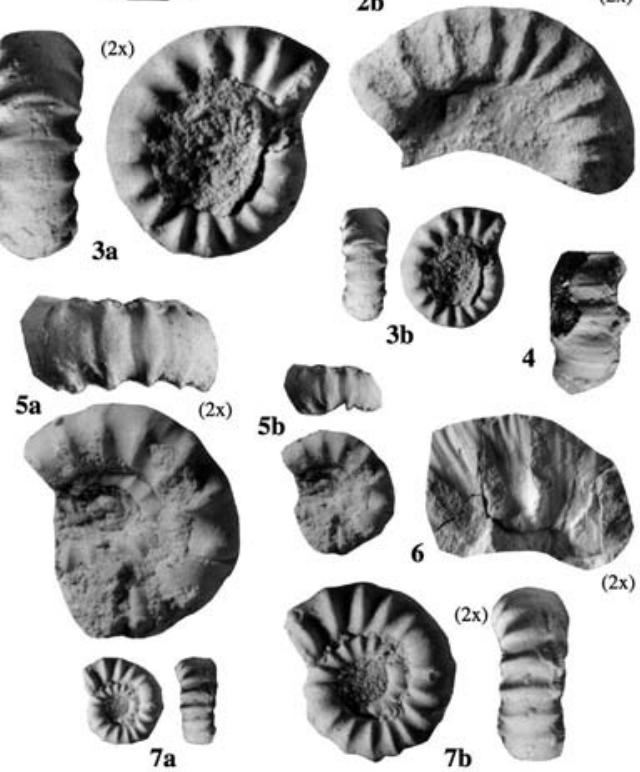

Figure 5 Bifericeras donovani Dommergues and Meister bed $73 b$, Donovani Horizon, Taylori Subzone, Lower Pliensbachian. 


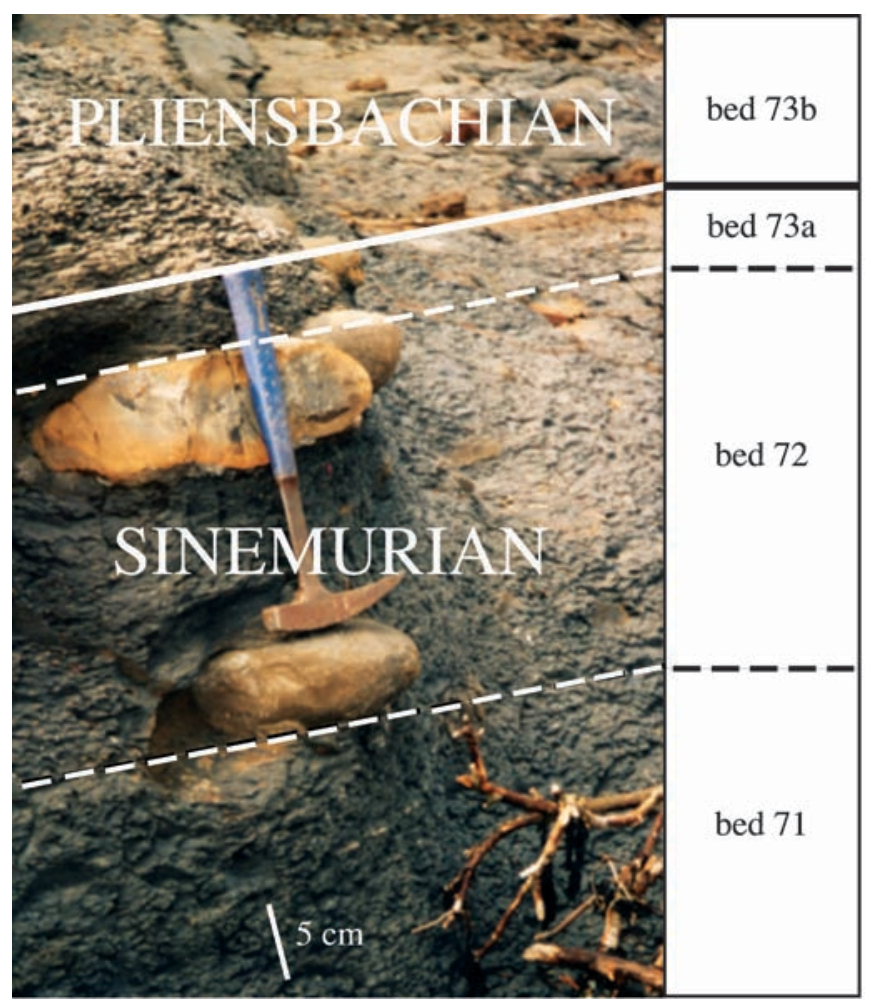

Figure 6 Detail of the Sinemurian-Pliensbachian boundary in Wine Haven (from Meister et al., 2003).

ently terminate in the Raricostatum Zone, while others seem to have originated in the Jamesoni Zone. In western Europe, these include Protocardia truncata (J. de C. Sowerby) which ranges from the Lower Pliensbachian Jamesoni Zone to the Toarcian Tenuicostatum Zone, whilst Protocardia philippiana (Dunker) occurs in Hettangian and Sinemurian strata (e.g. Hallam, 1987). First occurrences of bivalve species in the Jamesoni Zone are also recorded for the limids Pseudolimea acuticostata (Münster) and Pseudolimea cristata (Dumortier) (see Cox, 1944), and for the anomalodesmatan bivalve Goniomya hybrida (Münster).

A correlation chart for several circum-Pacific regions based on bivalves has been compiled by Damborenea et al. (1992). For South America, the Otapiria neuquensis Assemblage Zone has been recognized, which is approximately coeval to the Jamesoni, Ibex and Davoei zones (Riccardi et al., 1990).

\section{Foraminifera}

A total of 34 samples were collected (on two separate visits) in order to investigate the fossil changes across the Sinemurian-Pliensbachian boundary in Robin Hood's Bay. Only four samples yielded any fauna and all are located in the uppermost Sinemurian. All species are all well known Lower Jurassic taxa and belong to longranging morphogroups. The taxonomic details of these species and subspecies are listed in Meister et al. (2003, p. 286). All the other samples were barren.

The presence of Dentalina matutina (d'Orbigny) is diagnostic of the Sinemurian - Pliensbachian boundary (Copestake and Johnson, 1989) while the first occurence of Frondicularia terquemi muelensis is seen at the base of the Raricostatum Zone in the British Jurassic. The long-ranging, characteristic members of Early Jurassic foraminiferal assemblages are also present at this locality: Lingulina tenera tenera, Lingulina tenera tenuistriata, Lenticulina muensteri muensteri and Marginulina prima prima indicating normal marine conditions and connections with the other basins during this period. In their review of Lower Jurassic foraminifera, Copestake and Johnson (1989) indicate that the boundary is marked by the first occurence of Vaginulinopsis denticulatacarinata (Franke). As no samples above the boundary yielded any fauna we did not record this taxon. Copestake and Johnson (1989) record this species in the Northern North Sea Basin, the Moray Firth Basin, the Southern North Sea Basin, the Cleveland Basin (which includes Robin Hood's Bay) and the East Midlands Shelf. In the same range charts (Copestake and Johnson, 1989, figures 6.2.8, 6.2.9, 6.2.10) it is also indicated that the boundary is marked by the extinction of Nodosaria issleri Franke, but this taxon has not been found in our investigation.

Aside from the published charts (Copestake and Johnson, 1989, figures 6.2.6-6.2.10) in the Stratigraphical Atlas of Fossil Foraminifera there are very little published data available on coeval successions in the UK. The most comprehensive account of foraminifera from the Lower and Middle Lias is that by Copestake (1978) on the Mochras Borehole. Summary charts of some of these data are available in Copestake (1985) and Copestake and Johnson (1984) - much of which is repeated in their 1989 compilation.

The Dorset Coast does provide a potential succession for investigation but the only published information is provided by Copestake (1987). In this 'Field Guide' Copestake lists the foraminifera from a few 'spot' samples in the Upper Sinemurian (top of Black Ven Marls) and the Lower Pliensbachian (Belemnite Marls and Green Ammonite Beds). The lowermost sample from the Lower Pliensbachian (Copestake, 1987, figure 5; sample D12) contains only Bathysiphon sp., Lenticulina muensteri s.s. and Marginulina prima rugosa. The latter taxon is a long-ranging Sinemurian-Pliensbachian form and provides no detailed stratigraphic information. Sample D13 was taken from the upper part of the Belemnite Marls and while there are some new taxa present; this mid-Pliensbachian fossil change (Copestake and Johnson, 1989, figure 6.2 .9) is well above the level of the proposed GSSP.

The taxonomy of all of these species and subspecies is available in a number of Ph.D. theses (Copestake, 1978; Muller, 1990; Hylton, 2000 ) in the United Kingdom, but the only published summary is that in Copestake and Johnson (1989). However, a synthesis of the 'larger' foraminifera ranges for Europe and North Africa is given by Bassoulet (1997).

\section{Palynology}

A subset of 12 samples, out of the 34 samples collected for micropalaeontological investigations, has been selected for a palynological study. These samples cover the whole interval of interest across the Sinemurian - Pliensbachian boundary from the Macdonelli Subzone to the Taylori Subzone [lower part of bed 75].

All samples yielded a rich palynological residue with palynomorphs being moderately well-preserved. Composition of the organic residues (= palynofacies) is quite similar in all samples. The palynofacies is generally composed of high amounts of opaque phytoclasts, some brown translucent phytoclasts, translucent degraded phytoclasts, and few to no amorphous organic matter (AOM), high amounts of pollen grains, some spores, very few acritarchs, prasinophytes and foraminiferal test linings. Amorphous organic matter is abundant only in the two samples from bed 69. Dinoflagellate cysts have not been found in any of the samples investigated.

In all the palynological samples studied, the pollen and spore assemblages are very similar and correspond to assemblages known from Lower Jurassic sediments elsewhere in Europe (e.g. Weiss, 1989; Rauscher and Schmitt, 1990). No characteristic change in the assemblages has been encountered. This was to be expected since pollen and spores have relatively little potential in Jurassic stratigraphy and enable only a gross biostratigraphical breakdown of the period in an early, middle and late Jurassic unit (e.g. Weiss, 1989).

The palynomorph group with the best palynostratigraphical potential in marine Jurassic sediments is dinoflagellate cysts. Especially from the Toarcian/Aalenian onward dinoflagellate cyst biostratigraphy can achieve a resolving power in the order of ammonite Zones. However, only very few dinoflagellate cysts are known from the Sinemurian and the Pliensbachian. The uppermost Sinemurian and lowermost Pliensbachian interval is considered by some authors to be barren of dinoflagellate cysts (e.g. Stover et al., 1996), whereas 
others report the scarce occurrences of small dinoflagellate cysts with inconspicuous morphologies (Mancodinium/Maturodinium spp., Valvaeodinium spp., Dapcodinium spp., ?Beaumontella sp.) (e.g. Feist-Burkhardt and Wille, 1992, Feist-Burkhardt, 1998). However, the number of palynological studies with precise ammonite control is low and therefore the stratigraphical ranges of these species are not exactly known so far.

In the present palynological study no dinoflagellate cysts at all have been found. This is in agreement with a previous study on the organic microplankton from the Sinemurian - Pliensbachian of Yorkshire by Bucefalo Palliani and Riding (2000), who analysed spot samples from Robin Hood's Bay and came to the same results. Their two samples from the siliceous shale (Raricostatum Zone) at Robin Hood's Bay were barren of dinoflagellate cysts, as well as the one sample from the Lower Pliensbachian (Davoei Zone) from the neighbouring Cowbar Nab section. The same authors describe monospecific samples from underlying sediments of the Oxynotum Zone with Liasidium variabile Drugg as the only dinoflagellate cyst present. Abundant occurrence of that species in the Oxynotum Zone from Robin Hood's Bay was already known from the first description of L. variabile by Drugg (1978). A critical review of the pertinent literature seems to confirm the range top of L. variabile in the Late Sinemurian Oxynotum Zone to be a reliable stratigraphical marker datum (Feist-Burkhardt, ongoing study). Similar results, with productive samples from Oxynotum Zone and barren samples from Raricostatum and earliest Jamesoni Zones, were also reported from the Brown Moor borehole, some $50 \mathrm{~km}$ away from Robin Hood's Bay (Bucefalo Palliani and Riding, 2000).

The palynofacies of the studied samples is characterised by high amounts of terrigenous phytoclasts, pollen and spores. Marine components are rare, but present in all samples and composed of acritarchs, prasinophytes and foraminiferal test linings. The high amounts of terrigenous components together with minor amounts of amorphous organic matter is typical for a nearshore oxygenated environments with strong terrigenous input. The abundance of amorphous organic matter in both samples from bed 69 is interpreted as the result of less oxygenated conditions.

In conclusion, the palynological study provides little information in support of the selection of Wine Haven as GSSP because of the absence of dinoflagellate cysts. Thanks to its consistent occurrence, the range top of $L$. variabile in the Late Sinemurian Oxynotum Zone is considered to be a reliable stratigraphical marker datum.

\section{Ostracoda}

Very few ostracod valves were found. As a result, it has not been possible to produce a definitive statement on the fossil changes at this level. The only taxon identified is Ogmoconcha sp. Lord (1978) records that the base of the Pliensbachian is marked by the appearance of Ogmoconcha contractula Triebel and Gammacythere ubiquita Malz and Lord in N.W. Germany, although in the UK the appearance of both taxa is slightly above the Sine-
murian-Pliensbachian boundary. Lord (1978, figure 4) also indicates that Liasina lanceolata (Apostolescu) appears either just below, at, or just above the boundary in various parts of Europe (although the stratigraphical range in the Robin Hood's Bay succession is not given). Aside from the published work of Lord, the only other information on Liassic ostracoda remains unpublished (see Clarke, 1969; Field, 1968). Two synthesis are proposed for European marine and limnic ostracods by respectively Bodergat (1997) and Colin (1997).

\section{Correlation potential}

On the basis of ammonite assemblages the European Pliensbachian presently comprises 5 'Standard Chronozones', further subdivided into 15 Chronosubzones (Dean et al., 1961) and very often into detailed horizons sensu Callomon (1995) (see Meister et al., 2003 , figure 2). The standard zonation (zone, subzone, horizon) is tentatively correlated with different zonations/biohorizons proposed for the Tethyan or Pacific regions and shows quite good potential for biochronological correlations between the different paleogeographical areas even if some taxonomic problems occur. (see also Dommergues et al., 1983; Meister, 1995, Dommergues et al., 1997; Palfy et al., 2000; Blau and Meister, 2000; Meister et al., 2005). This proposed zonation and correlation is based on the most recent ammonite data available from the literature (Figures 7, 8,9).

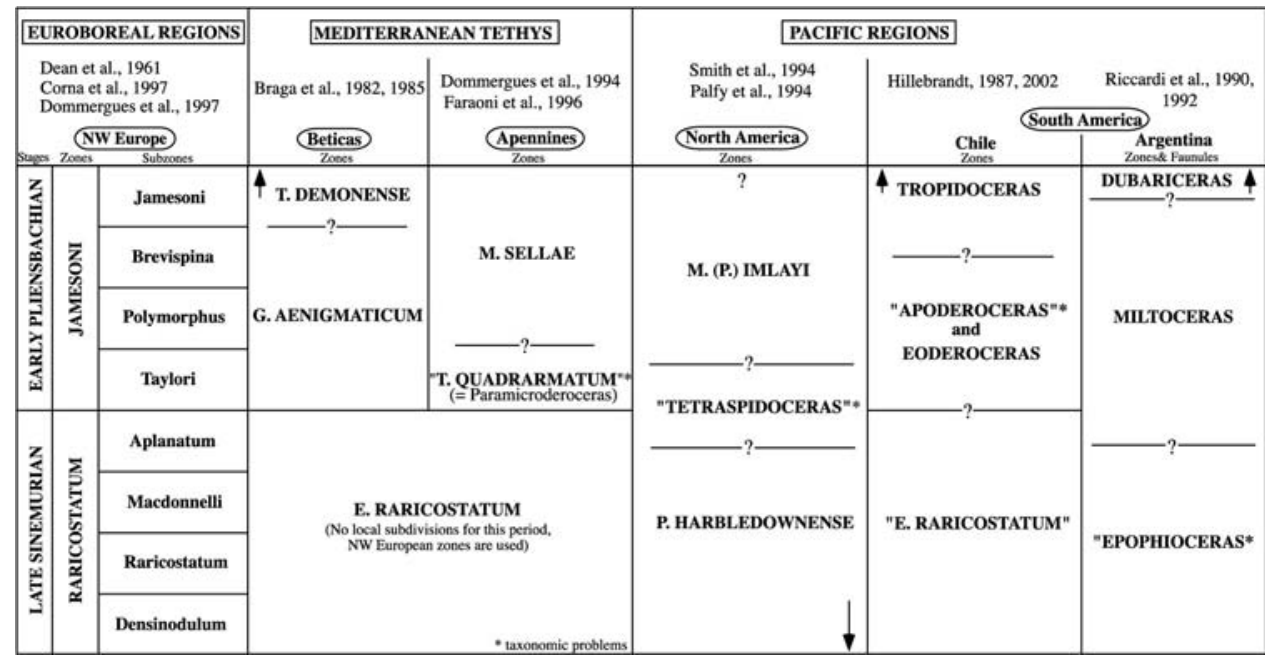

Figure 7 Tentative zonal correlations between Euroboreal regions, Mediterranean Tethys and Pacific regions (* indicates unresolved taxonomic problems).

\begin{tabular}{|c|c|c|c|c|}
\hline 焉 & 营 & SUBZONES & $\begin{array}{c}\text { HORIZONS } \\
\text { NW Europe and adjacent areas } \\
\text { Dean et al., 1961; Meister, 1995; Corna et al., 1997; } \\
\text { Dommergues et al., 1997; Blau \& Meister, 2000 }\end{array}$ & $\begin{array}{l}\text { GSSP: WINE HAVEN,YORSHIRE } \\
\text { Dommergues \& Meister, 1992; Howarth, 2002; } \\
\text { Meister et al., 2003 }\end{array}$ \\
\hline \multirow{7}{*}{ 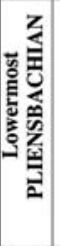 } & \multirow{7}{*}{ 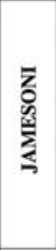 } & Jamesoni & Uptonia jamesoni - bronni & soni - bronni \\
\hline & & \multirow{2}{*}{ Brevispina } & Platypleuroceras submuticum / Platy. tenuilobus & $?$ \\
\hline & & & Platypleuroceras brevispina / Platy. brevispinoides & P. brevispina \\
\hline & & Polymorphus & ? Polymorphites polymorphus / E. (Coelod.) biruga & Platy. caprarium \\
\hline & & \multirow{3}{*}{ Taylori } & Phricodoceras taylori / Apoderoceras ssp. & P. taylori / P. cormutum / Apoderoceras ssp. \\
\hline & & & *A. nodogigas / T. quadrarmatum / A. gr. aculeatum & A. gr. aculeatum/A subtriangulare/P. taylori \\
\hline & & & Bifericeras donovani & B. donovani \\
\hline \multirow{7}{*}{ 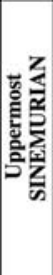 } & \multirow{7}{*}{ 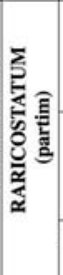 } & \multirow{3}{*}{ Aplanatum } & Paltechioceras tardecrescens / Palt. romanicum & P. tardecrescens / P. aff. romanicum / E. armatum-miles \\
\hline & & & Palt. tardecrescens / Palt. oosteri / Palt. recticostatum & P. tardecrescens / E. armatum-miles \\
\hline & & & Paltechioceras aureolum & P. aureolum / E. armatum-miles \\
\hline & & \multirow{3}{*}{ Macdonnelli } & Leptechioceras meigeni / Leptechioceras macdonnelli & L. meigeni / L. macdonnelli \\
\hline & & & Leptechioceras meigeni & L. meigeni \\
\hline & & & Leptechioceras meigeni / Paltechioceras charpentieri & \multirow{2}{*}{$\begin{array}{c}\text { Paltechioceras planum } \\
? \\
\end{array}$} \\
\hline & & $\begin{array}{c}\text { Raricostatum } \\
\text { (partim) }\end{array}$ & Paltechioceras liciense / Paltechioceras rothpletzi & \\
\hline
\end{tabular}

Figure 8 Biohorizon successions for the NW European regions and for the GSSP (Wine Haven) and correlations. 


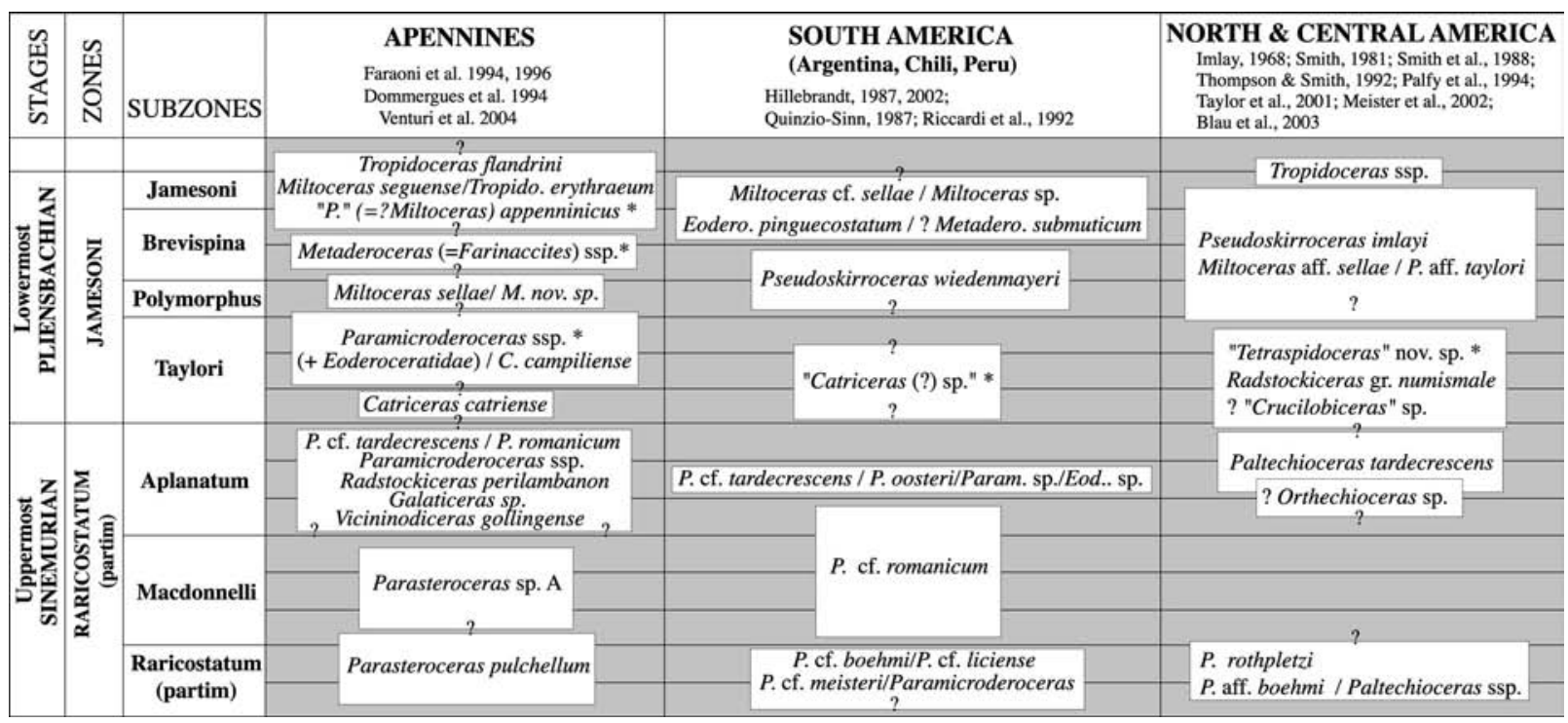

Figure 9 Proposed biohorizon succession for the Apennines (Mediterranean Tethys) and America (Pacific regions) and tentative correlations with the "standard" zones and subzones (* indicates unresolved taxonomic problems).

Studies on other biostratigraphic zonal schemes for the Pliensbachian are in progress (belemnites, bivalvia, brachiopods, ostracods, foraminifera, dinoflagellate cysts, calcareous nannofossils). They have been synthesized by Dommergues in 1997 and are completed here by S. Feist-Burkhardt and by M. Aberhan (Figures 10 and 11). Information about the ranges of echinoids and dasyclade algae are also provided respectively by Thierrry et al. (1997) and Bassoulet (1997).

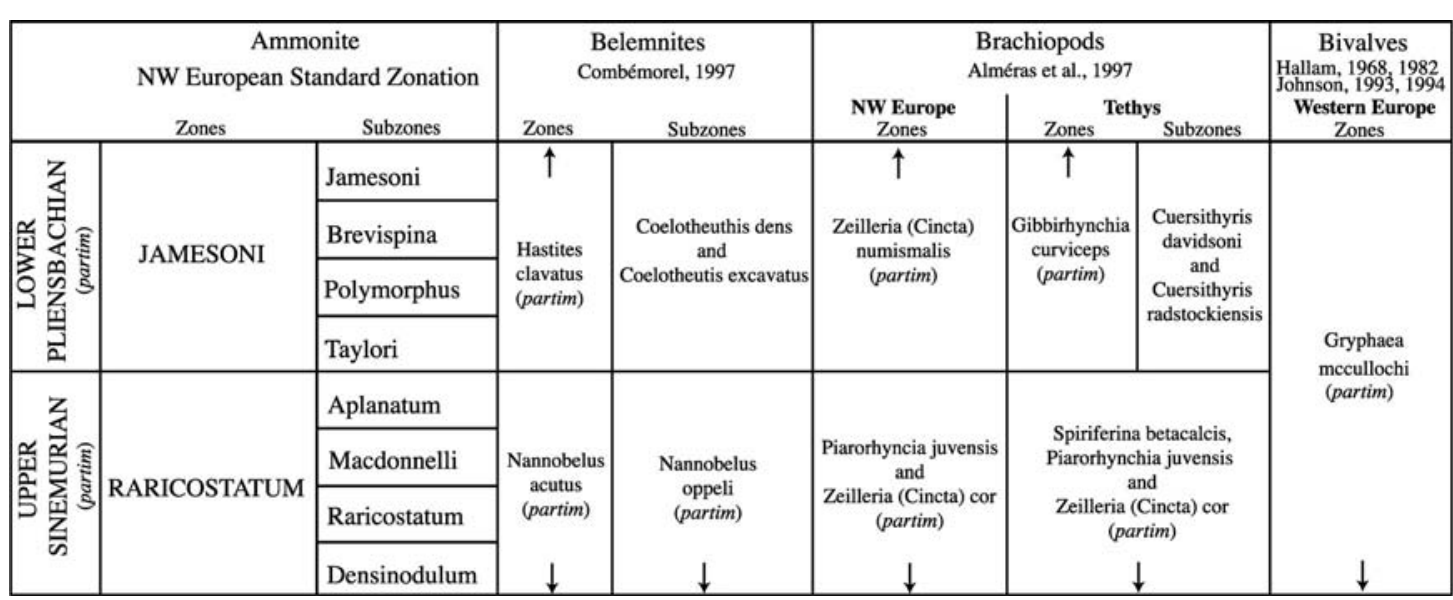

Figure 10 Zonal and subzonal correlations for ammonites, belemnites, brachiopods and bivalves (from Dommergues, 1997 and completed by Aberhan).

\section{Isotope stratigraphy}

Strontium isotope data derived from belemnites collected across the Sinemurian - Pliensbachian boundary have been reported previously by Hesselbo et al. (2000). Their results are reproduced in Figure 4. The data confirm the results of Jones et al. (1994) and provide a high-resolution record. A ${ }^{87} \mathrm{Sr} /{ }^{86} \mathrm{Sr}$ ratio of $0.707425 \pm 0.000021$ is recorded for the boundary. The data also suggest continuous sedimentation across the boundary section because there is no abrupt change in values at this level.

Stable-isotope data were also obtained by Hesselbo et al. (2000) from the same belemnites. Oxygen isotope data $\left(\delta^{18} \mathrm{O}\right)$ show a marked rise of about 1 per mil over the $10 \mathrm{~m}$ interval sampled in detail (Figure 3 ), equivalent to a water temperature drop of about $5{ }^{\circ} \mathrm{C}$ if interpreted only in those terms (as opposed

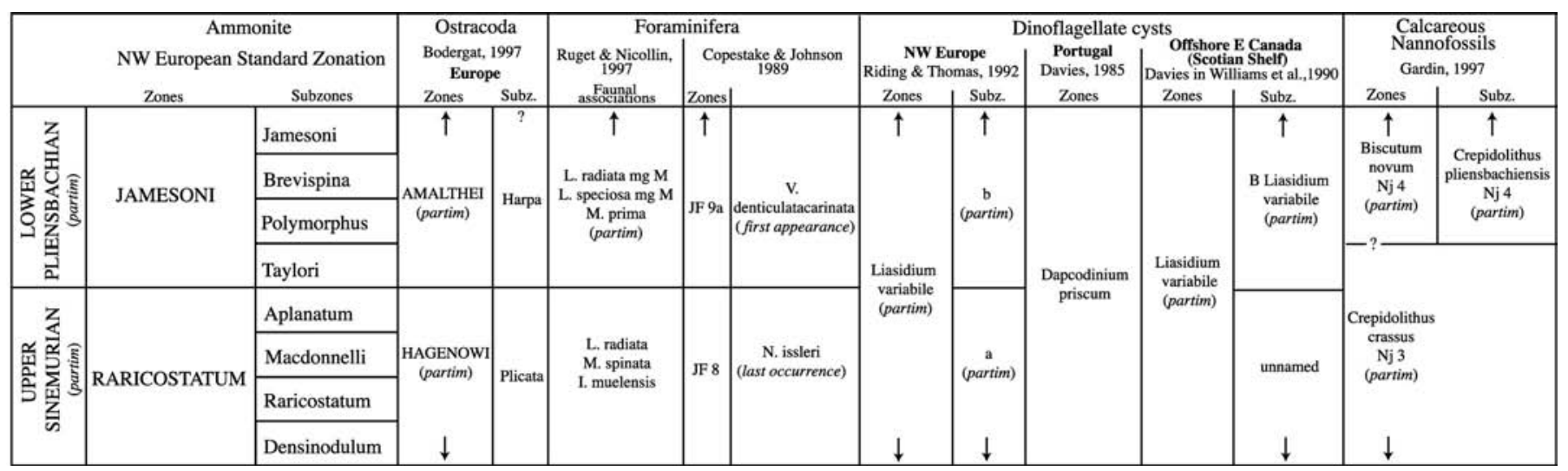

Figure 11 Zonal and subzonal correlations for ammonites, ostracods, foraminifera, dinoflagellate cysts and calcareous nannofossils (from Dommergues, 1997 and completed by Feist-Burkhardt). 
to changes in background water mass oxygen isotope values or habitat preferences of the organisms, for example). Carbon-isotope data from belemnites around the boundary interval show considerable scatter, but 'notably' they conform to the general pattern of relatively low values evident from other localities in Europe (Jenkyns et al., 2002). High-resolution carbon-isotope stratigraphy based on analysis of other materials may yet lead to identification of a recognizable and correlatable pattern at the Sinemurian - Pliensbachian boundary.

\section{Magnetostratigraphy: Winehaven to Boggle Hole Section, Robin Hood's Bay}

A set of 22 oriented samples was collected for paleomagnetic study across the Pliensbachian-Sinemurian boundary in the Winehaven to Boggle Hole cliff/foreshore section. The samples were taken at a fairly wide spacing, to test the possibility of defining a magnetostratigraphy for the section. Various lithologies were sampled, including siderite concretions, siltstones, silty mudstones and silty limestones. The prepared specimens were measured on either a JR5A spinner

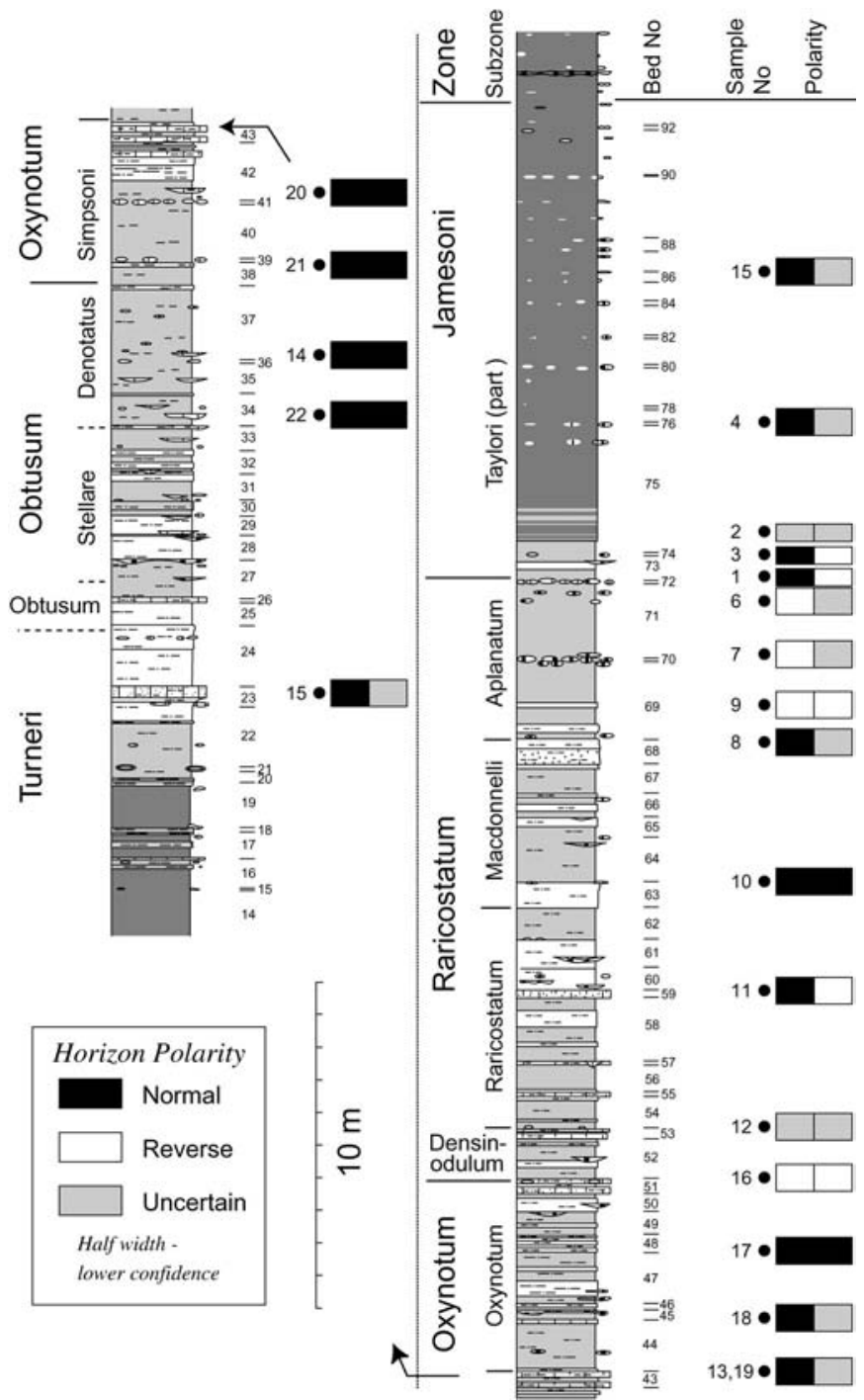

Figure 12 Summary magnetostratigraphy of the samples from the Winehaven to Boggle Hole section, Robin Hood's Bay. The lithological log and bed numbers are from Hesselbo and Jenkyns (1995). Magnetostratigraphic sample numbers are indicated, adjacent to the sampling position. $10 \mathrm{~m}$ scale in $1 \mathrm{~m}$ increments. magnetometer, or a GM400 CCL squid magnetometer. The NRM intensities range from 1.7 to $0.007 \mathrm{~mA} / \mathrm{m}$. Trials of the magnetisation behaviour during thermal demagnetisation suggest that heatinginduced magnetomineralogical changes commonly occurred between 250 and $350{ }^{\circ} \mathrm{C}$. Consequently, most of the samples were treated to thermal demagnetisation up to $250{ }^{\circ} \mathrm{C}$ (some to $325^{\circ} \mathrm{C}$ ), followed by alternating field demagnetisation. This is similar to the best procedure identified by Yang et al. (1996) and Moreau et al (2002) in paleomagnetic studies of the Lower Jurassic of the Paris Basin (see also Hounslow et al. 2004). In the present study, one to three specimens were measured from most horizons, usually two per horizon. The analysis of these data is not yet complete, and a preliminary assessment is presented here. Most of the specimens show a $\mathrm{N}$ to NE downward-directed magnetisation (i.e. normal polarity), with a smaller number displaying either NW downward magnetisations, southerly upwards-directed magnetisations (i.e. reverse polarity), or demagnetisation paths showing progressive isolating of a southerly directed magnetisation. The later two types are interpreted as reverse polarity magnetisations. Hence, the interpretation suggests that specimens show either reverse or normal polarity Jurassic-like magnetisations, but some appear to be quite strongly contaminated by a 'present-day like' magnetisation.

These data define a reverse polarity interval within the Aplanatum Subzone (Figure 12), represented by samples from three horizons, extending from the lower part of bed 69 to the top part of bed 71 of Hesselbo and Jenkyns (1995). This magnetozone appears to provide a useful datum for correlation, since its top appears to be $<0.5 \mathrm{~m}$ below the base of the Pliensbachian. A further reverse polarity interval has been tentatively identified, possibly spanning parts of

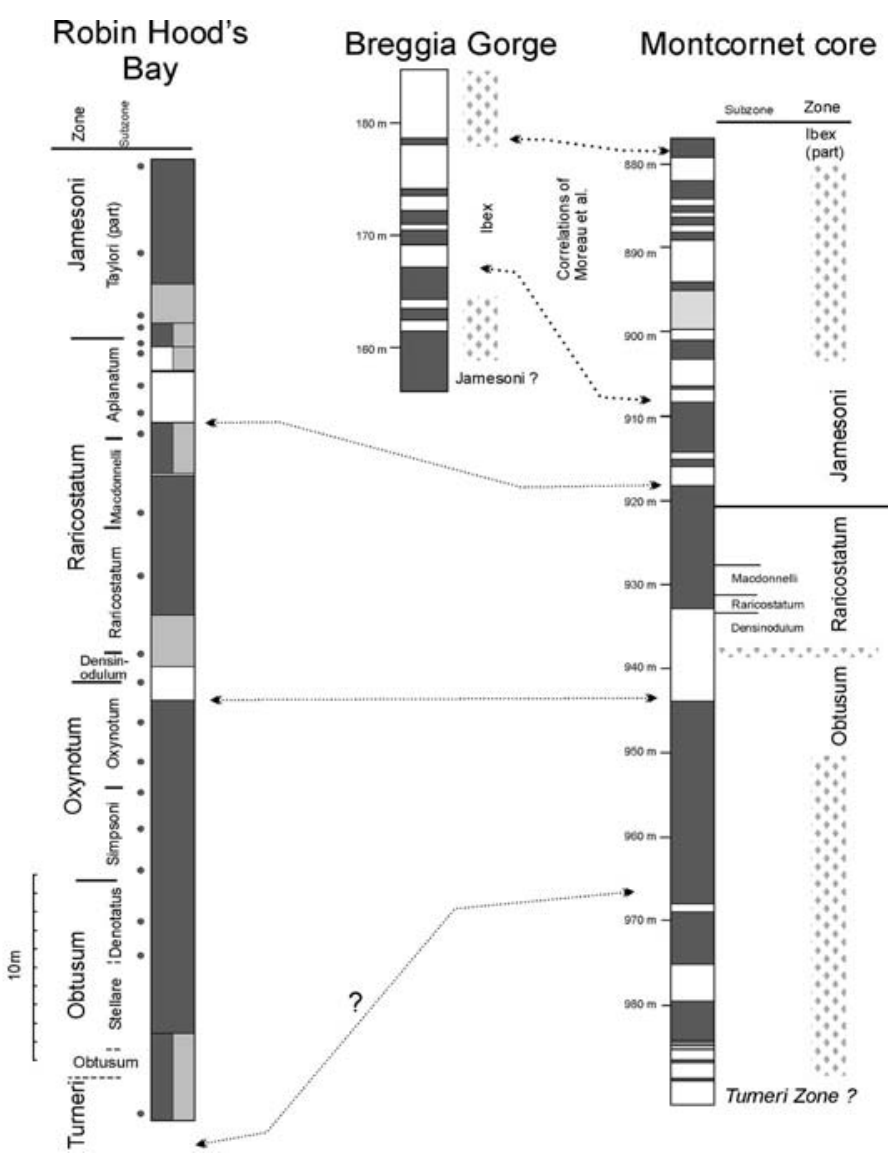

Figure 13 Comparison of the Robin Hood's Bay section to the base of the Pliensbachian section at Breggia Gorge, Switzerland (Horner and Heller, 1983) and the late Sinemurian succession in the Montcornet core (Yang et al., 1996; Moreau et al., 2002). Each is drawn in depth scale. Grey dotted interval represents uncertainty in placement of the biostratigraphic boundaries, and arrows probable correlations of magnetozones. 
the Oxynotum and Densinodulum Subzones of the Sinemurian, although it is currently defined by results only from sample level 16 (Figure 12). These two reverse polarity intervals appear to be embedded within a predominantly normal polarity interval which spans the late Turneri Zone through to the middle part of the Jamesoni Zone.

This preliminary magnetostratigraphy compares well with the published studies from the Breggia Gorge in Switzerland (Horner and Heller, 1983), and the Montcornet borehole from the Paris Basin (Yang et al., 1996; Moreau et al., 2002). The reverse magnetozone at sample level 16 best equates with the reverse magnetozone from Montcornet, which there ranges from the mid uppermost part of the Obtusum Zone to the Raricostatum Subzone (Figure 13). However, Yang et al. (1996) found no diagnostic ammonites for the Oxynotum Zone, nor for the upper part of the Obtusum Zone. Consequently, the lower boundary of this reverse magnetozone cannot be placed with certainty relative to the biostratigraphy at Montcornet. However at Winehaven, this reverse magnetozone clearly starts in the Oxynotum Subzone.

From the data of Yang et al. (1996) a predominantly normal magnetozone extends downward into the lower part of the Obtusum Zone, where reverse polarity magnetozones occur, which we have not detected. This may be either because of our wide sample spacing in this part of the section, or alternatively the lack of good evidence for the position of the Turneri Zone in the Montcornet core. Hence, this normal magnetozone may extend into the Turneri Zone, as it appears to do in the Robin Hood's Bay sections (Figure 13).

The magnetostratigraphy suggests that the reverse magnetozone within the Aplanatum Subzone at Winehaven probably correlates to the reverse magnetozone between $918-915 \mathrm{~m}$ in the Montcornet core (Figure 13). However, Moreau et al. (2002) placed the position of the Jamesoni Zone in the Montcornet core at $920.65 \mathrm{~m}$ on the basis of the occurrence of the ammonite Polymorphites sp. at $920.7 \mathrm{~m}$ (indicative of Jamesoni Zone), above Paltechioceras gr. tardecrescens at $920.6 \mathrm{~m}$ (indicative of the Aplanatum Subzone). The magnetostratigraphic correlation and presence of Paltechioceras tardecrescens at both Winehaven and Montcornet are contradictory. Diagnostic ammonite fauna at other levels within the Raricostatum or Jamesoni Zones at Montcornet were lacking, and hence it may be that either the sparse ammonite fauna is misleading, or magnetisation acquisition at the Winehaven section was delayed in comparison to that at Montcornet. The sparse sampling in the Jamesoni Zone at Winehaven cannot discount the possibility that further reverse magnetozones might be present within this Zone.

Magnetostratigraphic studies from condensed pelagic limestones at Bakonycsernye (Márton et al., 1980), Fonte Avellana and Cingoli (Channell et al.,1984) show a dominance of reverse polarity across the Sinemurian- Pliensbachian boundary, in stark contrast to results presented here. This may be because the chronostratigraphy in these sections has both poor biostratigraphic control and hiatuses in the thin pelagic limestone successions may be frequent, as suggested by Opdyke and Channel (1996).

\section{Conclusion}

The GSSP for the base of the Pliensbachian is formally proposed at the base of bed 73b of the Wine Haven Section. The section fulfills most of the requirements indicated in the Guidelines of the International Commission on Stratigraphy (ICS) (Remane et al., 1996):

- Succession of about $30 \mathrm{~m}$ of pale grey and buff-coloured sandy mudstones which pass upward very gradually into silty dark grey shales.

- Absence of unconformities in the Sinemurian-Pliensbachian interval and continuous exposure.

- Correlation by means of ammonites which are abundant and quite well preserved and supplemented by Strontium isotope stratigraphy.
- Easy accessibility of the section well exposed on the cliff and the foreshore.

- No structural complexity or metamorphism.

- Part of a Site of Special Scientific Interest and, therefore, protected under U.K. legislation.

- The GSSP does not include potential chronometers for radiometric dating.

- A discreet reverse polarity magnetozones are present and spans much of the latest Sinemurian Aplanatum Subzone. It terminates $<0.5 \mathrm{~m}$ below the Sinemurian-Pliensbachian boundary and may prove a valuable chronostratigraphic marker.

\section{Acknowledgements}

We are grateful to all the members of the Pliensbachian Working Group (see Appendix I) who sent us comments and suggestions. We also thank the Birhäuser Verlag AG (Eclogae Geologicae Helvetiae) for their permission to reproduce some figures.

\section{Appendix I}

Pliensbachian Working Group as at 1997-98

J. Blau (Germany), J. Bloos (Germany), J.H. Callomon (UK), G. Cassinis (Italy), R.B. Chandler (UK), E. H. Chellai (Morocco), M. J. Comas Rengifo (Spain), M. Corna (France), S. Damborenea (Argentina), J.-L. Dommergues (France), D. T. Donovan (UK), P. Doyle (UK), K. Dybkjaer (Denmark), R. Ebel (Germany), K. El Hariri (Morocco), L. Emmanuel (France), P. Faraoni (Italy), S. Feist-Burkhardt (UK), A. Ferretti (Italie), B. Géczy (Hungary), A. Görög (Hungary), R. L. Hall (Canada), M. B. Hart (UK), G.F.W. Herngreen (The Netherlands), S. Hesselbo (UK), A. von Hillebrandt (Germany), M. K. Howarth (UK), M.D. Hylton (UK), Huyen Dang Tran (Vietnam), D. Jutson (Denmark), E. Koppelhus (Denmark), F. Macchioni (Italy), M. O. Mancenido (Argentina), A. Marini (Italy), C. Meister (Switzerland), S. Meledina (Russia), M. Monostori (Hungary), R. Mouterde (France), R. Myczynski (Poland), K. Page (UK), J. Palfy (Hungary), G. Pallini (Italy), N. E. Poulsen (Denmark), G. Price (UK), A. C. Riccardi (Argentina), J. Riding (UK), P. Rivas (Spain), R. Rocha (Portugal), I. G. Sapunov (Bulgaria), P. Schirolli (Italy), R. Schlatter(Germany), R. Schmidt-Effing (Germany), P. L. Smith (Canada), G. Stevens (New Zealand), I. Svente (Hungary), P. Tchoumatchenko (Bulgaria), H. Tipper (Canada), F. Venturi (Italy), $\mathrm{Vu}$ Khuc (Vietnam)

\section{References}

Almeras, Y., Boullier, A., and Laurain, B., 1997, Brachiopodes. In E. Cariou et P. Hantzergue (coord.), Biostratigraphie du Jurassique ouest-européen et méditerranéen: zonations parallèles et distribution des invertébrés et microfossiles, Groupe Français d'études du Jurassique: Bulletin du Centre Recherche Elf, Exploration et Production, mém. 17, pp. 169-195.

Bairstow, L.F., 1969, Lower Lias. In: J.E. Hemingway, J.K. Wright and H.S Torrens (eds), International Field Symposium on the British Jurassic, Excursion Guide Number 3, NE Yorkshire, University of Keele, pp. C24C28.

Bassoulet, J.-P., 1997, Foraminifères. In E. Cariou et P. Hantzergue (coord.), Biostratigraphie du Jurassique ouest-européen et méditerranéen: zonations parallèles et distribution des invertébrés et microfossiles, Groupe Français d'études du Jurassique): Bulletin du Centre Recherche Elf, Exploration et Production, mém. 17, pp. 293-304.

Bassoulet, J.-P., 1997, Algues dasycladales. In E. Cariou et P. Hantzergue (coord.), Biostratigraphie du Jurassique ouest-européen et méditerranéen: zonations parallèles et distribution des invertébrés et microfossiles, Groupe Français d'études du Jurassique: Bulletin du Centre Recherche Elf, Exploration et Production, mém. 17, pp. 339-341.

Blau, J., and Meister, C., 2000, Upper Sinemurian ammonite successions based on 41 faunal horizons: an attempt at worldwide correlation. In R.L. 
Hall and P.L. Smith (eds), Advances in Jurassic Research: GeoResearch Forum, v. 6, pp. 3-12.

Blau, J., Meister, C., Schlatter, R., and Schmidt-Effing, R., 2003, Ammonites from the Lower Jurassic (Sinemurian) of Tenango de Doria (Sierra Madre Oriental, Mexico). Part III: Echioceratidae: Revue de Paléobiologie, v. 22, pp. 421-437.

Bodergat, A.-M., 1997, Ostracodes marins. In E. Cariou et P. Hantzergue (coord.), Biostratigraphie du Jurassique ouest-européen et méditerranéen: zonations parallèles et distribution des invertébrés et microfossiles, Groupe Français d'études du Jurassique: Bulletin du Centre Recherche Elf, Exploration et Production, Mém. 17, pp. 197-223.

Braga, J.C., Comas Rengifo, M.J., Goy, A., and Rivas, P., 1982, Comparacione faunisticas y correlaciones en el Pliensbachiense de la Zona Subbética y Cordillera Ibérica: Bolletin de la real Sociedad española de Historia naturale, v. 80, pp. 221-244.

Braga, J.C., Martin-Algara, A., and Rivas, P., 1985, Ammonites du Lias inférieur (Sinémurien - Lotharingien) de Sierra Harana (Cordillères bétiques, Espagne). In 1er Colloque Centre International d'Etude du Lias: Cahiers de l'Université Catholique de Lyon, v. 14, pp. 85-100.

Bucefalo Palliani R., and Riding, J.B., 2000, A palynological investigation of the Lower and lowermost Middle Jurassic strata (Sinemurian to Aalenian) from North Yorkshire, UK: Proceedings of the Yorkshire Geological Society, v. 53, pp. 1-16.

Buckman, S.S., 1909-1930, Yorkshire Type Ammonites; then: Type Ammonites. Wheldon and Wesley edit. (detailed reference in Dean, Donovan and Howarth 1961), pp. 1-7, pl. 909.

Callomon, J.H., 1995, Time from fossils: S.S. Buckman and Jurassic highresolution geochronology. In M.J. Le Bas (ed), Milestones in Geology: Geological Society of London, mem. 16, pp. 127-150.

Channell, J.E.T., Lowrie, W., Pialli, P., and Venturi, F., 1984, Jurassic magnetic stratigraphy from Umbrian (Italian) land sections: Earth and Planetary Science Letters, v. 68, pp. 309-325.

Clarke, A.R., 1969, The Ostracoda of the Scottish Lias: Unpublished Ph.D. Thesis, University of London.

Colin, J.-P., 1997, Ostracodes limniques. In E. Cariou et P. Hantzergue (coord.), Biostratigraphie du Jurassique ouest-européen et méditerranéen: zonations parallèles et distribution des invertébrés et microfossiles, Groupe Français d'études du Jurassique: Bulletin du Centre Recherche Elf, Exploration et Production, mém. 17, pp. 273-279.

Combémorel, R., 1997, Bélemnites. In E. Cariou et P. Hantzergue (coord.), Biostratigraphie du Jurassique ouest-européen et méditerranéen: zonations parallèles et distribution des invertébrés et microfossiles, Groupe Français d'études du Jurassique: Bulletin du Centre Recherche Elf, Exploration et Production, mém. 17, pp. 157-167.

Cope, J.C., Getty, T.A., Howarth, M.K., Morton, N., and Torrens, H.S., 1980, A correlation of Jurassic Rocks in the British Isles. Part one: Introduction and Lower Jurassic: Special Report of the Geological Society of London, no. 14.

Copestake, P., 1978, Foraminifera from the Lower and Middle Lias of the Mochras Borehole: Unpublished Ph.D. Thesis, Univ. College of Wales, Aberystwyth.

Copestake, P., 1985, Foraminiferal biostratigraphy in the Lower Jurassic. In O. Michelson and A. Zeiss, (eds), Proceed. Internat. Symposium on Jurassic Stratigraphy, Erlangen, 1984: Geological Survey of Denmark, v. 1, pp. 192-206.

Copestake, P., 1987, Dorset Jurassic. Mesozoic and Cenozoic stratigraphical micropalaeontology of the Dorset coast and Isle of Wight, Southern England. In A.R. Lord and P.R. Bown (eds), Field Guide for the XXth European Micropalaeont: Colloq., British Micropalaeontological Society, Guide Book 1, pp. 1-78.

Copestake, P., and Johnson, B., 1984, Lower Jurassic (Hettangian - Toarcian) foraminifera from the Mochras Borehole, North Wales (U.K.) and their application to a worldwide biozonation. Benthos '83; Second International Symposium on Benthic Foraminifera, Pau, April 1983, pp. 183184.

Copestake, P., and Johnson, B., 1989, The Hettangian to Toarcian (Lower Jurassic). In D.G. Jenkins and J.W. Murray (eds), Stratigraphical Atlas of Fossil Foraminifera: British Micropalaeontological Society Series, Ellis Horwood, Chichester, pp. 81-105.

Corna, M., Dommergues, J.-L., Meister, C., and Mouterde, R., 1997, Sinémurien. In E. Cariou et P. Hantzergue (coord.), Biostratigraphie du Jurassique ouest-européen et méditerranéen : zonations parallèles et distribution des invertébrés et microfossiles, Groupe Français d'études du Jurassique): Bulletin du Centre Recherche Elf, Exploration et Production, mém. 17, pp. 9-14, pp. 106-113.

Cox, L.R., 1944, On Pseudolimea Arkell: Proceedings of the Malacological Society London v. 26, pp. 74-88.
Cox, B.M., 1990, A review of Jurassic chronostratigraphy and age indicators for the UK. In R.F.P. Hardman and Brooksj. (eds), Tectonic Events Responsible for Britain's Oil and gas reserves: Geological Society, London, Special publication, v. 55, pp. 169-190.

Damborenea, S.E., Polubotko, I.V., Sey, I.I., and Paraketsov, K.V., 1992 Bivalve zones and assemblages of the circum-Pacific region. In Westermann, G.E.G. (ed.). The Jurassic of the circum-Pacific, Cambridge University Press, pp. 300-307.

Davies, E.H., 1985, The miospore and dinoflagellate cysts Oppel-zonation of the Lias of Portugal: Palynology v. 9, pp. 105-132.

Dean, W.T., Donovan, D.T., and Howarth, M.K., 1961, The Liassic ammonite Zones and Subzones of the North West European Province: Bulletin of the Natural History Museum, v. 4, pp. 435-505.

Dommergues, J.-L., 1997, Chapitre III. Synthèses biochronologiques. Le Jurassique inférieur. In E. Cariou et P. Hantzergue (coord.), Biostratigraphie du Jurassique ouest-européen et méditerranéen : zonations parallèles et distribution des invertébrés et microfossiles, Groupe Français d'études du Jurassique): Bulletin du Centre Recherche Elf, Exploration et Production, mém. 17, pp. 347-353.

Dommergues, J.-L., Ferretti, A., Geczy, B., and Mouterde, R., 1983, Eléments de corrélation entre faunes d'ammonites mésogéennes (Hongrie, Italie) et subboréales (France, Portugal) au Carixien et au Domérien inférieur: Geobios, v. 16, pp. 471-499.

Dommergues, J.-L., Ferretti, A., and Meister, C., 1994, Les faunes d'ammonites du Sinémurien de l'Apennin Central (Marches et Toscane, Italie) Bollettino della Società Geologica Italiana, v. 33, pp. 13-42.

Dommergues, J.-L., Laurain, B., and Meister, C., 1996, Evolution of ammonoid morphospace during the Early Jurassic: Palaebiolology, v. 22, pp. 219-240.

Dommergues, J.-L., and Meister, C., 1990, Les faunes d'ammonites liasiques de l'Austroalpin moyen dans les Alpes Rhétiques italiennes (Région de Livigno); biostratigraphie et implications paléogéographiques: Revue de Paléobiologie, v. 9, pp. 291-307.

Dommergues, J.-L., and Meister, C., 1992, Late Sinemurian and Early Carixian ammonites in Europe with cladistic analysis of sutural characters: Neues Jahrbuch für Geologie und Paläontologie Abhandlungen, v. 185, pp. 211-237.

Dommergues, J.-L., Meister, C., and Mouterde, R., 1997, Pliensbachien. In E. Cariou et P. Hantzergue (coord.), Biostratigraphie du Jurassique ouesteuropéen et méditerranéen: zonations parallèles et distribution des invertébrés et microfossiles, Groupe Français d'études du Jurassique) Bulletin du Centre Recherche Elf, Exploration et Production, mém. 17 pp. 15-23, pp. 114-119

Dommergues, J.-L., Page, K.N., and Meister, C., 1994, A detailed correlation of Upper Sinemurian (Lower Jurassic) ammonite horizons between Burgundy (France) and Britain: Newsletters on Stratigraphy, v. 30, pp. 6173

Drugg, W.S., 1978, Some Jurassic dinoflagellate cysts from England, France and Germany: Palaeontographica B, v. 168, pp. 61-79.

Faraoni, P., Marini, A., Pallini, G., and Venturi, F., 1994, Nuove faune ad ammoniti delle zone ad E. mirabilis ed H. serpentinus nella Valle del F. Bosso (PS) e loro riflessi sulla biostratigrafia del limite Domeriano-Toarciano in Appennino: Studi Geologica Camerti, special volume, pp. $247-$ 297.

Faraoni, P., Marini, A., Pallini, G., and Venturi, F., 1996, New Carixian ammonite assemblages of Central Apennines (Italy), and their impact on Mediterranean Jurassic biostratigraphy: Paleopelagos v. 6, pp. 75-122.

Feist-Burkhardt, S., 1998, Palynostratigraphic characterization of the Sinemurian-Pliensbachian transition of the potential GSSP section at Aubach/Aselfingen, Southwest Germany: Abstracts. 5th International Symposium Jurassic System, Vancouver no. 29.

Feist-Burkhardt, S., and Wille, W., 1992, Jurassic palynology in southwest Germany - state of the art: Cahiers de Micropaléontologie v. 7, no. 1-2, pp. 141-164.

Field, R.A., 1968, Lower Jurassic Ostracoda from England and Normandy: Unpublished Ph.D. Thesis, University of London.

Fox-Strangways, C., and Barrow, C., 1882, The geology of the country between Whitby and Scarborough: Memoirs of the Geological Survey of England and Wales, $66 \mathrm{p}$.

Gad, M.A., 1966, A geochemical study of the Liassic rocks of the Yorkshire coast: PhD Thesis, University of London.

Gardin, S., 1997, Nannofossiles calcaires. In E. Cariou et P. Hantzergue (coord.), Biostratigraphie du Jurassique ouest-européen et méditerranéen: zonations parallèles et distribution des invertébrés et microfossiles, Groupe Français d'études du Jurassique): Bulletin du Centre Recherche Elf, Exploration et Production, mém. 17, pp. 305-329. 
Getty, T.A., 1972, Revision of the Jurassic ammonite family Echioceratidae: Unpublished Ph.D Thesis, University of London, pp. 1-319.

Getty, T.A., 1973, A revision of the generic classification of the family Echioceratidae (Cephalopoda, Ammonoidea) (Lower Jurassic): University of Kansas Paleontological Contributions, v. 63, pp. 1-32.

Graciansky, P.-C., De, Dardeau, G., Dommergues, J.-L., Durlet, C., Goggin, V., Marchand, D., Dumont, T., Hesselbo, S., Jacquin, T., Meister, C., Mouterde, R., Rey, J., and Vail, P.R., 1998, Ammonite biostratigraphic correlation and Early Jurassic sequence stratigraphy in France: comparisons with some UK sections: Society of Economic Paleontologists and Mineralogists (S.E.P.M.), Special Publication, no. 60, pp. 583-622.

Greensmith, J.T., Rawson, P.F., and Shalaby, S.E., 1980, An association of minor fining-upward cycles and aligned gutter marks in the middle Lias (lower Jurassic) of Yorkshire: Proceedings of the Yorkshire Geological Society, v. 42, pp. 525-538.

Hallam, A., 1961, Cyclothems, transgressions and faunal change in the Lias of north-west Europe: Transactions of the Edinburgh Geological Society, v. 18 , pp. 124-174.

Hallam, A., 1967, An environmental study of the upper Domerian and Lower Toarcian in Great Britain: Philosophical Transactions of the Royal Society of London, ser. B, no. 252, pp. 393-445

Hallam, A., 1968, Morphology, palaeoecology and evolution of the genus Gryphaea in the British Lias: Philosophical Transactions of the Royal Society of London, ser. B, no. 254, pp. 91-128.

Hallam, A., 1976, Stratigraphic distribution and ecology of European Jurassic bivalves: Lethaia, v. 9, pp. 245-259.

Hallam, A., 1981, A revised sea-level curve for the early Jurassic: Journal of the Geological Society of London, 138, 735-743.

Hallam, A., 1982, Patterns of speciation in Jurassic Gryphaea: Paleobiology, v. 8, pp. 354-366.

Hallam, A., 1987, Radiations and extinctions in relation to environmental change in the marine Lower Jurassic of northwest Europe: Paleobiology, v. 13 , pp. $152-168$

Hemingway, J.K., Wilson, V., and Wright, C.W., 1968, Geology of the Yorkshire Coast. Geologists' Association Guides (ed.) S.W. Hester., Colchester no. 34, 50 p.

Hesselbo, S.P., and Jenkyns, H.C., 1995, A comparison of the Hettangian to Bajocian successions of Dorset and Yorkshire. In P. D. Taylor (ed.), Field Geology of the British Jurassic: The Geological Society, pp.105-150.

Hesselbo, S.P., and Jenkyns, H.C., 1998, British Lower Jurassic Sequence Stratigraphy. In P. C. De Graciansky, J. Hardenbol, T. Jacquin and P.R. Vail (eds), Mesozoic and Cenozoic Sequence Stratigraphy of European Basins: Special Publication Society for Sedimentology (SEPM), no. 60, pp. 561-581.

Hesselbo, S.P., Meister, C., and Gröcke, D.R., 2000, A potential global stratotype for the Sinemurian-Pliensbachian boundary (Lower Jurassic), Robin Hood's Bay, UK: ammonite faunas and isotope stratigraphy: Geological Magazine, v. 137, pp. 601-607.

Hillebrandt, A., von, 1987, Liassic Ammonite zones of South America and correlations with other Provinces. With description of new genera and species of ammonites. In Bioestratigrafia de los Sistemas Regionales del Jurassico y Cretacico en America del Sur, Mendoza: pp.111-157.

Hillebrandt, A., von, 2002, Ammoniten aus dem oberen Sinemurium von Südamerika: Revue de Paléobiologie, v. 21, pp. 35-147.

Horner, F., and Heller, F., 1983, Lower Jurassic magnetostratigraphy at the Breggia Gorge (Ticino, Switzerland) and Alpe Turati (Como, Italy): The Geographical Journal of the Royal Astronomical Society, v. 73, pp. 705718 .

Hounslow, M.W., Posen, P.E., and Warrington, G., 2004, Magnetostratigraphy and biostratigraphy of the Upper Triassic and lowermost Jurassic succession, St. Audrie's Bay, UK: Palaeogeography, Palaeoclimatology, Palaeoecology, v. 213, pp. 331-358.

Howard, A.S., 1985, Lithostratigraphy of the Staithes Sandstone and Cleveland Ironstone formations (Lower Jurassic) of north-east Yorkshire: Proceedings of the Yorkshire Geological Society, v. 45, pp. 261-275.

Howarth, M.K., 1955, Domerian of the Yorkshire Coast: Proceedings of the Yorkshire Geological Society, v. 30, pp. 147-175.

Howarth, M.K., 1958, The ammonites of the Liassic family Amaltheidae in Britain (II): Palaeontographical Society, pp. 27-53, pp. XV-XXXVII.

Howarth, M.K., 1992, The ammonite family Hildoceratidae in the Lower Jurassic of Britain: Monographs of the Paleontographical Society, part. I and II $145,146,200 \mathrm{p}$.

Howarth, M.K., 2002, The Lower Lias of Robin Hood's Bay, Yorkshire, and the work of Leslie Bairstow: Bulletin of the Natural History Museum, no. 58 , pp. 81-152.
Hylton, M.D., 2000, Microfaunal investigation of the Early Toarcian (Lower Jurassic) extinction event in N.W. Europe: Unpublished Ph.D. Thesis, University of Plymouth.

Imlay, R.W., 1968, Lower Jurassic (Pliensbachian and Toarcian) ammonites from eastern Oregon and California: U. S. Geological Survey Professional Paper, no. 593c, 51 p.

Jenkyns, H.C., Jones, C.E., Gröcke, D.R., Hesselbo, S.P., and Parkinson, D.N., 2002, Chemostratigraphy of the Jurassic System: applications, limitations and implications for palaeooceanography: Journal of the Geological Society, v. 159, pp. 351-378.

Johnson, A.L.A., 1993, Punctuated equilibria versus phyletic gradualism in European Jurassic Gryphaea evolution: Proceedings of the Geologists' Association London, v. 104, pp. 209-222.

Johnson, A.L.A., 1994, Evolution of European Lower Jurassic Gryphaea (Gryphaea) and contemporaneous bivalves: Historical Biology, Chur, no. 7, pp. 167-186.

Jones, C.E., Jenkyns, H. C., and Hesselbo, S.P., 1994, Strontium isotopes in Early Jurassic seawater: Geochimica Cosmochimica Acta, v. 58, pp. $1285-1301$

Lang, W.D., 1928, The Belemnite Marls of Charmouth, a series in the Lias of the Dorset Coast: Quarterly Journal of the geological Society of London, v. 84 , pp. $179-257$

Lord, A.R., 1978, The Jurassic Part 1 (Hettangian-Toarcian). In R. Bate and E. Robinson (eds), A stratigraphical index of British Ostracoda, Seal House Press, Liverpool, pp.189-212.

Márton, E., Márton, P., and Heller, F., 1980, Remanent magnetisation of a Plienbachian limestone sequence at Bakonycsernye (Hungary): Earth and Planetary Science Letters, v. 48, pp. 218-226.

Meister, C., 1995, Essai de corrélations au Lias moyen (Sinémurien supérieur et Carixien) entre les Pontides et les principales régions adjacentes de la Téthys occidentale et de l'Europe du nord-ouest: Hantkeniana, Géczy Jubilee v. 1, pp. 75-82.

Meister, C., 1997, Report of the Sinemurian - Pliensbachian Boundary Working Group: International Subcommission on Jurassic Stratigraphy Newsletter, no. 25 , pp. 34-37.

Meister, C., 1999a, Report of the Sinemurian - Pliensbachian Boundary Working Group: International Subcommission on Jurassic Stratigraphy Newsletter, no. 26, pp. 33-42.

Meister, C., 1999b, Report of the Sinemurian - Pliensbachian Boundary Working Group: International Subcommission on Jurassic Stratigraphy Newsletter, no. 27 , pp. 25-26

Meister, C., 2001, Pliensbachian Working Group: International Subcommission on Jurassic Stratigraphy Newsletter, no. 28, pp. 5-6.

Meister, C., 2002, Pliensbachian Working Group: International Subcommission on Jurassic Stratigraphy Newsletter, no. 29, pp. 4-6.

Meister, C., 2003, Pliensbachian Working Group: International Subcommission on Jurassic Stratigraphy Newsletter, no. 30, pp. 13-14.

Meister, C., 2004, Pliensbachian Working Group: International Subcommission on Jurassic Stratigraphy Newsletter, no. 31, p. 8

Meister, C., 2005, Pliensbachian Working Group: International Subcommission on Jurassic Stratigraphy Newsletter, no. 32, pp. 12-13.

Meister, C., Blau, J., Dommergues, J.-L., Feist-Burkhardt, S., Hart, M., Hesselbo, S.P., Hylton, M, Page, K., and Price, G., 2003, A proposal for the Global Boundary Stratotype Section and Point (GSSP) for the base of the Pliensbachian Stage (Lower Jurassic): Eclogae Geolologicae Helvetiae, v. 96 , pp. 275-297.

Meister, C., Blau, J., Dommergues, J.-L., J., Schlatter, R., Schmidt-Effing, R., and Burk, K., 2005, Ammonites from the Lower Jurassic (Sinemurian) of Tenango de Doria (Sierra Madre Oriental, Mexico). Part IV: Biostratigraphy, palaeobiogeography and taxonomic addendum: Revue de Paléobiologie, v. 24, pp. 365-384.

Meister, C., Blau, J., Schlatter, R., and Schmidt-Effing, R., 2002, Ammonites from the Lower Jurassic (Sinemurian) of Tenango de Doria (Sierra Madre Oriental, Mexico). Part II: Phylloceratoidea, Lytoceratoidea, Schlotheimiidae, Arietitinae, Oxynoticeratidae and Eoderoceratidae: Revue de Paléobiologie, v. 21, pp. 391-409.

Meister, C., and Stampfli, G., 2000, Les ammonites du Lias moyen (Pliensbachien) de la Néotéthys et de ses confins; compositions fauniques, affinités paléogéographiques et biodiversité: Revue de Paléobiologie, v. 19, pp. 227-292.

Moreau, M-G, Bucher, H., Bodergat, A-M., and Guex, J., 2002, Pliensbachian magnetostratigraphy: new data from Paris Basin (France): Earth and Planetary Science Letters, v. 203, pp. 755-767.

Muller, F.L., Jr, 1990, The palaeoecology of the Liassic benthic foraminifera of Great Britain: Unpublished Ph.D. Thesis, Graduate School, Rutgers University, The State University of New Jersey, USA. 
Opdyke, N.D., and Channell, J.E.T., 1996, Magnetic stratigraphy. Acedemic Press, San Diego.

Page, K., 1992, The sequence of ammonite correlated horizons in the British Sinemurian (Lower Jurassic): Newsletters on Stratigraphy, v. 27, pp. 129156.

Palfy, J., Smith, P.L., and Mortensen, J.K., 2000, A U-Pb and ${ }^{40} \mathrm{Ar} /{ }^{39} \mathrm{Ar}$ time scale for the Jurassic: Canadian Journal of Earth Sciences, v. 37, pp. 923944.

Palfy, J., Smith, P.L., and Tipper, H.W., 1994, Sinemurian (Lower Jurassic) ammonoid biostratigraphy of the Queen Charlotte Islands, western Canada: Geobios, v. 17, pp. 385-393.

Phelps, M.C., 1985, A refined ammonite biostratigraphy for the Middle and Upper Carixian (Ibex and Davoei Zones, Lower Jurassic) in North-West Eupope and stratigraphical details of the Carixian-Domerian boundary: Geobios, v. 18, pp. 321-362

Powell, J.H., 1984, Lithostratigraphical nomenclature of the Lias Group of the Yorkshire Basin. Proceedings of the Yorkshire Geological Society of London, v. 45, pp. 51-57

Quinzio-Sinn, L.A., 1987, Stratigraphische Untersuchungen im Unterjura des Südteils der Provinz Antofagasta in Nord-Chile: Berliner geowissenschaftliche Abhandlungen, reihe A, v. 87, pp. 1-100.

Rauscher, R., and Schmitt, J.-P., 1990, Recherches palynologiques dans le Jurassique d'Alsace (France): Revue de Palaeobotanique et Palynologie, v. 62 , pp. $107-156$

Rawson, P.F., and Wright, J.K., 1992, The Yorkshire Coast: Geologists Association Guide number 34 (2nd Edition), Geologists' Association, 117 p.

Rawson, P.F., and Wright, J.K., 1995, Jurassic of the Cleveland Basin, North Yorkshire. In P.D. Taylor (ed.), Field geology of the British Jurassic: Geological Society of London, pp. 173-208.

Remane, J., Bassett, M.G., Cowie, J.W., Gohrbandt, K.H., Lane, H.R., Michelsen, O., and Wang Naiwen, 1996, Revised guidelines for the establishment of global chronostratigraphic standards by the International Commission on Stratigraphy (ICS): Episodes, v. 19, pp. 77-81.

Riccardi, A. C., Damborenea, S. E., and Mancenido, M.O., 1990, 3. Lower Jurassic of South America and Antarctic Peninsula. In Westermann, G.E.G. and Riccardi, A.C. (eds.). Jurassic taxa ranges and correlation charts for the Circum Pacific. 3. South America and Antarctic Peninsula: Newsletters on Stratigraphy, v. 21, pp. 75-103.

Riccardi, A.C., Gulisano, C. A., Mojica, J., Palacios, O., Schubert, C., and Thomson, M.R.A., 1992, 6. Western South America and Antarctica. In Westermann, G. E. G. (ed.), The Jurassic of the Circum-Pacific, Cambridge University Press, Cambridge: pp. 122-161.

Riding, J.B., and Thomas, J.E., 1992, Dinoflagellate cysts of the Jurassic System. In Powell A.J. (ed.) A stratigraphic index of dinoflagellate cysts, Chapman and Hall, London, pp. 7-57.

Ruget, C., and Nicollin, J.-P., 1997, Foraminifères. In E. Cariou et P. Hantzergue (coord.), Biostratigraphie du Jurassique ouest-européen et méditerranéen: zonations parallèles et distribution des invertébrés et microfossiles, Groupe Français d'études du Jurassique): Bulletin du Centre Recherche Elf, Exploration et Production, mém. 17, pp. 281-291.

Schlatter, R., 1990, Phricodoceras sexinodosum n.sp. (Ammonoidea) aus dem Lotharingium (Raricostatum-Zone) von Balingen (Baden-Württemberg, Südwestdeutschland): Stuttgarter Beiträge zur Naturkunde, ser B, v. 159 , pp. 1-9.

Sellwood, B.W., 1970, The relation of trace fossils to small-scale sedimentary cycles in the British Lias. In T.P. Crimes and J.C. Harper (eds), Trace Fossils. Special Issue Geological Journal, no. 3, pp. 489-504.

Sellwood, B.W., 1971, The genesis of some sideritic beds in the Yorkshire Lias: Journal of Sedimentary Petrology, v. 41, pp. 854-858.

Senior, J., 1996, Yorkshire Rocks and Landscape. In C. Scrutton (ed), Yorkshire Geological. Society.

Simpson, M., 1843, A monograph of the ammonites of the Yorkshire Lias. London, pp. 1-60.

Simpson, M., 1855, The fossils of the Yorkshire Lias; described from nature [1ft edition]: London, Whitby (Whittaker), $149 \mathrm{p}$.

Simpson, M., 1865-68, A Guide to the Geology of the Yorkshire Coast. 4th ed. (recte 3rd edition) Whittaker and Co, London.

Smith, P.L., 1981, Biostratigraphy and ammonoid fauna of the Lower Jurassic (Sinemurian, Pliensbachian and lowest Toarcian) of eastern Oregon and western Nevada: Thesis Hamilton (Ont.) (McMaster University): xxiv +368 p.

Smith, P.L., Tipper, H.W., Taylor, D.G., and Guex, J., 1988, An ammonite zonation for the Lower Jurassic of Canada and the United States: the Pliensbachian: Canadian Journal of Earth Sciences, v. 25, pp. 1503-1523.

Spath, L.F., 1923, Correlation of the Ibex and Jamesoni Zones of the Lower Lias: Geological Magazine, v. 60, pp. 6-11.
Spath, L.F., 1925, Notes on Yorkshire Ammonites: The Naturalist, v. 6, pp. 107-364,

Stover, L.E., Brinkhuis, H., Damassa, S.P., De Verteuil, L., Helby, R.J., Monteil, E., Partridge, A.D., Powell, A.J., Riding, J.B., Smelror, M., and William, G.L., 1996, Mesozoic-Tertiary dinoflagellates, acritarchs and prasinophytes. In J. Jansonius and D.C. McGregor (eds), Palynology, principles and applications: American Association of Stratigraphic Palynologiste Foudation, no. 2, pp. 641-750.

Sylvester-Bradley, P.C., 1953, A stratigraphical guide to the fossil localities of the Scarborough district. In The natural history of the Scarborough district, 1. Geology and botany: Scarborough Field Naturalist's Society. Scarborough, $x$ ii +296 p.

Tate, R., and Blake, J.F., 1876, The Yorkshire Lias. J. van Voorst, London.

Taylor, D.G., Guex, J., and Rakus, M., 2001, Hettangian and Sinemurian ammonoid zonation for the Western Cordillera of North America: Bulletin de Géologie de l'université de Lausanne, no. 350, pp. 381-421.

Thierry, J., Clavel, B., Hantzpergue, P., Neraudeau, D., Rigollet, L., and Vadet, A., 1997, Echinodermes. In E. Cariou et P. Hantzergue (coord.), Biostratigraphie du Jurassique ouest-européen et méditerranéen: zonations parallèles et distribution des invertébrés et microfossiles, Groupe Français d'études du Jurassique): Bulletin du Centre Recherche Elf, Exploration et Production, mém. 17, pp. 253-271.

Thompson, R.C., and Smith, P.L., 1992, Pliensbachian (Lower Jurassic) biostratigraphy and ammonite fauna of the Spatsizi area, north-central British Columbia: Geological Survey of Canada, no. 437, 87 p.

Van Buchem, F.S.P., and Knox, R.W.O'B. McCave, 1998, Lower and Middle Jurassic Depositional Sequences of Yorkshire (U.K.). In P.C. De Graciansky, J. Hardenbol, T. Jacquin and P.R. Vail (eds), Mesozoic and Cenozoic Sequence Stratigraphy of European Basins: Society of Economic Paleontologists and Mineralogists, Special Publication Society for Sedimentology (SEPM), no. 60, pp. 545-559.

Van Buchem, F.S.P., McCave, I.N., and Weedon, G.P., 1994, Orbitally induced small-scale cyclicity in a siliciclastic epicontinental setting (Lower Lias, Yorkshire, UK). In P. L. De-Boer and D.G. Smith (eds), Orbital forcing and cyclic sequences: Special Publication of the International Association of Sedimentologists, no. 19, pp. 345-366.

Van Buchem, F. S.P., Melnyk, D.H., and McCave, I.N., 1992, Chemical cyclicity and correlation of lower Lias mudstones using gamma ray logs, Yorkshire, UK: Journal of the Geological Society, v. 149, pp. 991-1002.

Venturi, F., Nannarone, C., and Bilotta, M., 2004, Eoderoceratidae (Mollusca, Ammonoidea) from the 'Corniola' of the Central Apennines, related to the Sinemurian-Pliensbachian boundary in the mediterranean area: Bollettino della Società Paleontologica Italiana, v. 2, pp. 87-137.

Weedon, G.P., and Jenkyns, H.C., 1999, Cyclostratigraphy and the Early Jurassic time scale: data from the Belemnite Marls: Bulletin of the Geological Society of America, v. 43, pp. 361-382.

Weiss, M., 1989, Die Sporenfloren aus Rät und Jura Südwestdeutschlands und ihre Beziehung zur Ammoniten-Stratigraphie: Palaeontographica, Abt. B, v. 215, pp. 1-168.

Williams, G.L., Ascoli, P., Barss, M.S., Bujak, J.P., Davies, E.H., Fensome, R.A., and Williamson, M.A., 1990, Chapter 3. Biostratigraphy and related studies. In Keen M.J. and Williams G. L. (eds) Geology of the continental margin of eastern Canada: Geological Survey of Canada, Geology of Canada, v. 2, pp. 87-137.

Williamson, W.C., 1840, On the distribution of Fossil remains on the Yorkshire Coast, from the Lower Lias to the Bath Oolite inclusive: Transaction of the Geological Society 1840, pp. 223-242.

Yang, Z., Moreau, M-G., Bucher, H., Dommergues J-L., and Trouiller, A., 1996, Hettangian and Sinemurian magnetostratigraphy from the Paris Basin: Journal of Geophysical Research, v. 101, pp. 8025-8042.

Young, G.M., and Bird, J., 1822, A geological survey of the Yorkshire Coast: describing the strata and fossils occurring between the Humber and the Tees, from the German Ocean to the Plain of York. Whitby $366 \mathrm{p}$.

Young, G.M., and Bird, J., 1828, A geological survey of the Yorkshire Coast: describing the strata and fossils occurring between the Humber and the Tees, from the German Ocean to the Plain of York. 2nd ed. enlarged, Whitby 368 p. 
Christian Meister is a researcher at the Natural History Museum of Geneva since 1992 and convenor of the GSSP Pliensbachian working group since 1996. His research focuses on biostratigraphy, evolution and paleogeography of the Lower Jurassic ammonites in Europe, North Africa, Central and South America and Asia. His interest concerns also the African Cretaceous (Cenomanian-Turonian) ammonites connected with the transsaharian seaway and the opening of the South Atlantic.

Malcom Hart, after reading Geology at Imperial College (London University), remained in the Department of Geology as a PhD research student working with D.J. Carter on the foraminifera of the Albian - Turonian interval in Southern England. After completing his PhD he took up a position as Junior Lecturer at the University of Newcastle, before moving (in 1972) to Plymouth Polytechnic (later University of Plymouth). In 1981 he was appointed Professor of Micropalaeontology and has served the university in a number of positions (Head of Department, Dean of Research, Pro Vice-Chancellor (Research), and Associate Dean of Science). In a research career of almost 40 years he has published 160 research papers and edited 6 books. His main interest is Cretaceous foraminifera and biostratigraphy, but he has published on foraminifera, ostracods, holothurian sclerites, radiolarian, trace fossils, pteropods and rynchosaurs. His current interests include the origin and early evolution of planktonic foraminifera, the definition of the Oxfordian GSSP and the chronology of volcanic eruptions on the island of Montserrat (Caribbean Sea) using the micropalaeontology of marine cores.

Stephen P. Hesselbo is a lecturer in stratigraphy at the University of Oxford. His research work has focussed on broad aspects of Earth History during the Mesozoic. He is currently a member of the International Sub-commission on Jurassic Stratigraphy, and co-leader of the recently completed IGCP project 458 on Triassic-Jurassic Boundary Events.

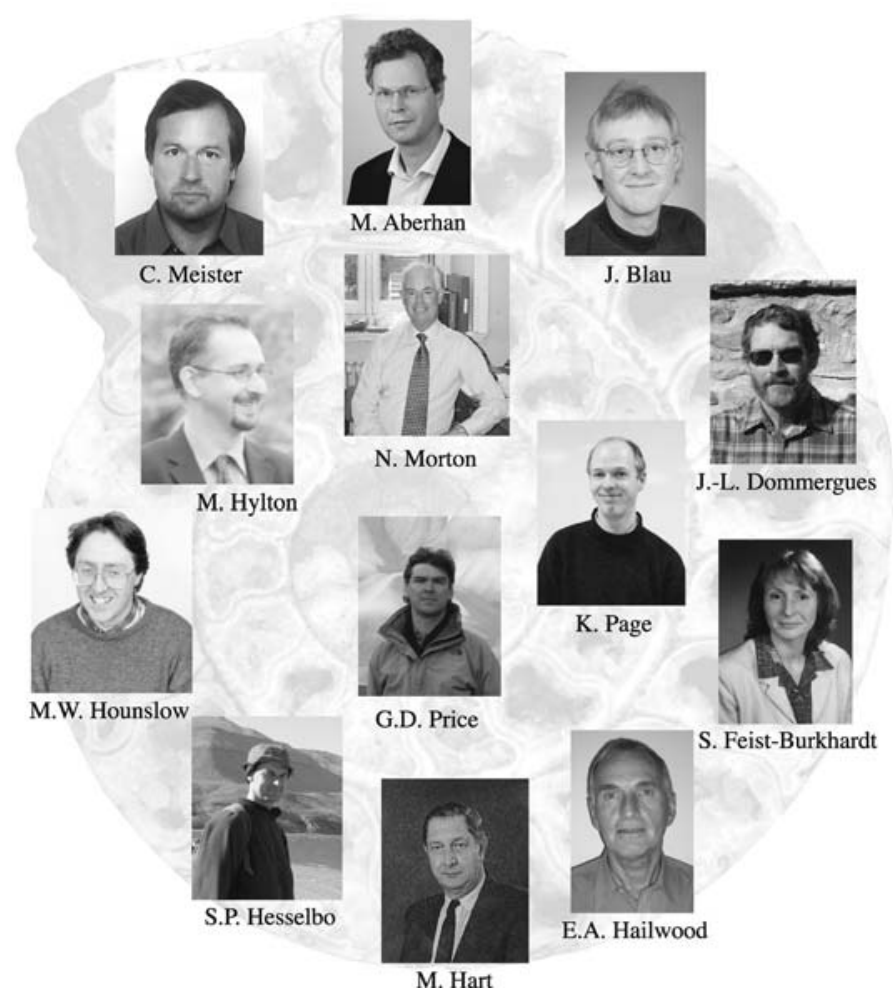

\section{Hutchison 'Young Scientist' Fund}

William Watt Hutchison, "Hutch" to his many friends around the world, was a Scots-born Canadian geologist who served Canada and the IUGS in myriad dynamic and creative ways. Most notably, he served as the IUGS Secretary General (1976-1980) at a pivotal time in its history, and as IUGS President (1984-1987). The same boundless energy, enthusiasm, skill in communications, and ability to foster teamwork that characterized his work with the IUGS also carried him to preeminent scientific administrative positions in the Canadian Government, where he served as Director General of the Geological Survey of Canada and as Assistant Deputy Minister of Earth Sciences. His distinguished career was terminated in 1987 by his untimely death at the age of 52, following a painful struggle with cancer.

One of Hutch's last wishes was to establish under IUGS auspices a memorial foundation intended to promote the professional growth of deserving, meritorious young scientists from around the world by supporting their participation in important IUGS-sponsored conferences. The first 3 beneficiaries of the Hutchison "Young Scientist" Foundation attended the 28th International Geological Congress (IGC) in Washington, D.C., in 1989.

Initially, earned interest on the funds available to the Hutchison Foundation were insufficient to sustain comparable grants every four years without seriously eroding the principal. For that reason, the IUGS made no grants from the Foundation for the 30th IGC (1996), preferring instead to strengthen the fund by allowing it to earn interest for a longer period of time and by appealing for donations from the international geologic community. Grants from the Foundation again supported deserving young scientists beginning with the 31st IGC (2000), and should continue for future Congresses. The IUGS would like to expand the resources of the Foundation to make it possible also to offer support to deserving young scientists to attend other important IUGS-sponsored scientific meetings. The Hutchison "Young Scientist" Foundation is a worthy cause that honors a fine, caring man and a distinguished, public-spirited scientist and administrator. The foundation also celebrates and promotes those things that gave Hutch the most professional satisfaction: geology, international scientific collaboration, and stimulating young minds.

The IUGS welcomes contributions to the Hutchison "Young Scientist" Foundation. Please send donations to:

Dr. Antonio Brambati

IUGS Treasurer

Dept. of Geological, Environmental and Marine Sci. (DiSGAM),

University of Trieste, 1-34127 Trieste, ITALY

Tel: +39040 558 2046; Fax: +39040 5582048

E-mail: brambati@univ.trieste.it

Checks in US dollars or Visa/Mastercard (please include account number and expiration date) are preferred in order to avoid the high cost of currency conversions. Residents of the U.S.A. are reminded that charitable gifts of this nature are tax deductible. 